تأثير توأم شيب جانبى سيلابدشت و شيب كانال اصلى در يك كانال مركب، بر انتقال رسوبات عاطفه عرب و كاظم اسماعيلى

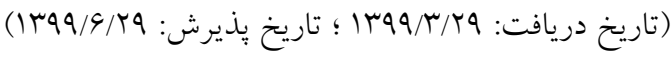

جكيده

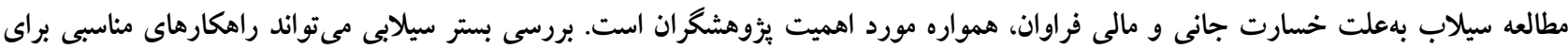

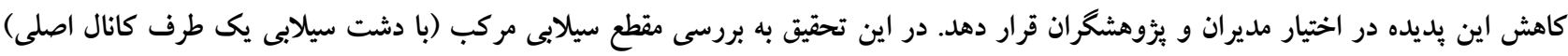

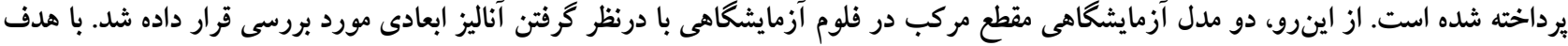

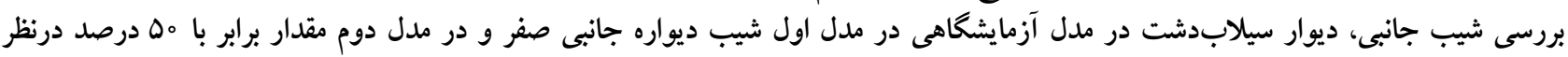

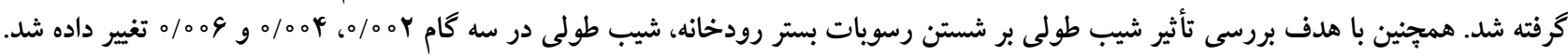

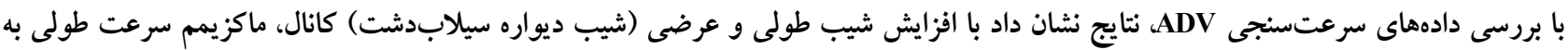

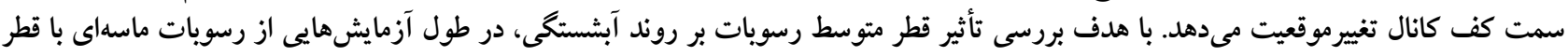

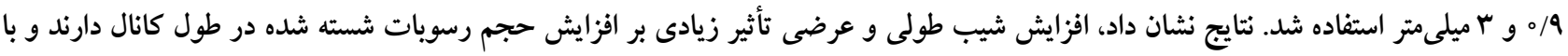

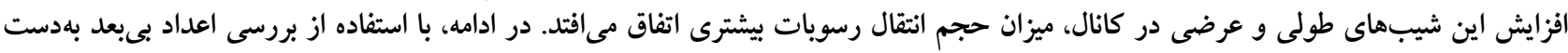

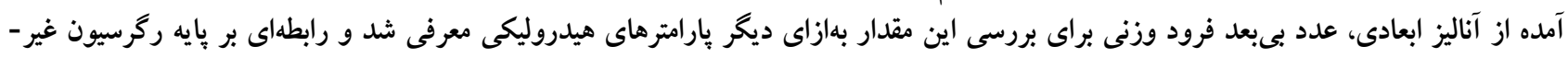

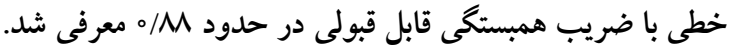

وازههاى كليدى: مقاطع مركب، سيلابدشت، شيب طولى كانال، رسوب، شيب عرضى، رگرسيون غيرخطى، آناليز ابعادى 


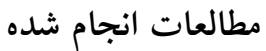

روش هاى زيادى براى تحليل هيدروليك جريان در كانـالهـاى

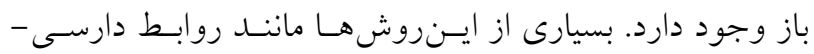
ويسباخ، شزى و مانينگ براى مقاطع ساده مناسب بوده اما بــراى مقاطع مركب مستقيم و وييجــانرود محهـدوديت دارنـــ. بنـابراين، مدلهاى رياضى يـك بعـدى معمـول در مهندسى هيـدروليكى جريان و رسوب (MIKE11، HEC-RAS و ISIS) كه مبتنى بـر روابط مانينگ يا شزى است، براى تحليـل جريـان در رودخانـه هاى با مقطع مركب قابل اعتماد نيستند. در اين مدلهـا از روش تر تجزيه قائم مقطع مركب براى محاسبه دبى جريان سيل اسـتفاده مىشود كه محدوديت اصلى ايسن روش، درنظـر نخــفتن تسنش برشى ايجاد شده در مرز تماس مقطع اصسلى و دشـت سـيلابى است. با صرف نظر كردن از اين تنش، خطاى زيادى در محاسبه دبى جريان بهويزه در رودخانههاى طبيعى بهوجود مى آيد (11). يكى از روشهاى مرسوم مطالعه مقاطع مركب استفاده از مــل -

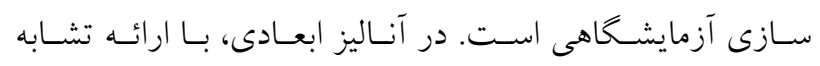

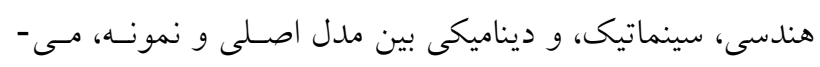

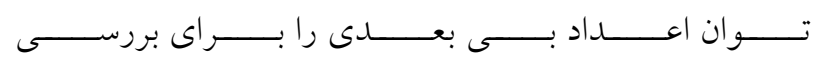
يار امترهاى مختلف هيدروليكى و فيزيكى حاكم بر جريان ارائسه كرد (14) در مطالعهاى يزووهشخران به بررسى مدل سيلابدشت يـك

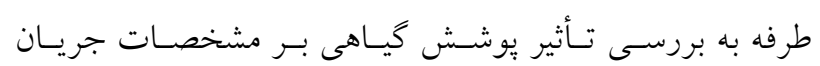
يرداختند. اينطور بيان شد كه با افزايش يوشش كيـاهى، ارتفــاع

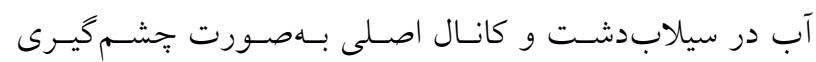
افزايش بيدا كرد. اخر جهه افزايش بوشش گياهى مىتوانـد باعـث

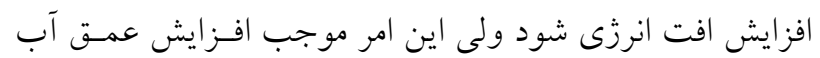

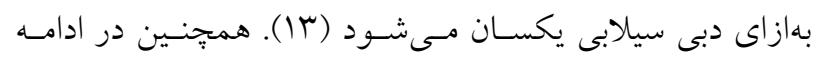

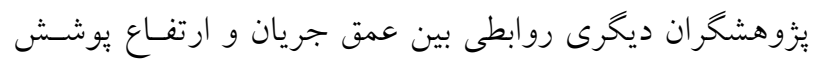

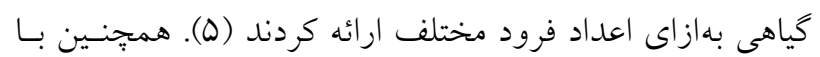
درنظر كرفتن يارامترهـاى هيـدروليكى و ميـزان تـراكم بوشـش
بيش از سه دهه است كه هيدروليك جريان در مقاطع مركب توسط بزوهشـحران مختلـف مـورد مطالعـه و بررسسى قـرار

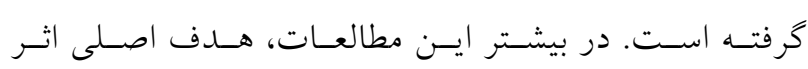
يارامترهــاى فيزيكـى و هيــدروليكى بـــر ســاختار جريــان هيدروليكى كانال اسـت. مشخصـات هيـدرولكى جريـان در كانال اصلى و دشت سيلابى كاملاً با يكديخر متفاوت بودهه و بههمين دليل براى محاسبات هيدروليكى ايسن مقـاطع، بايسـ

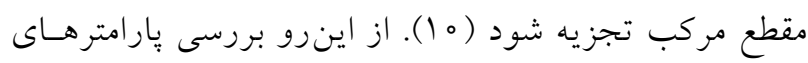
فيزيكى و هيدروليكى مىتواند بهصورت مجزا يا بسهصورت

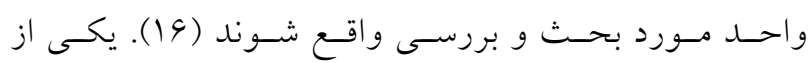
يارامترهاى مورد اهميت در اين مطالعات شيب طولى كانال و شيب عرضى سيلاب دشت است. در حالت كلى و بـا توجسه به رابطه لين (Lane (1998) تنش وارده به كف كانال توسط جريان تابع مستقيمى از شيب طولى كانال اسـت. در روابـط

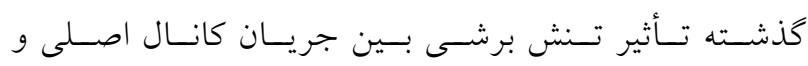
سيلابدشت صفر درنظر گرفته مىشد. از جمله ايسن روابـط

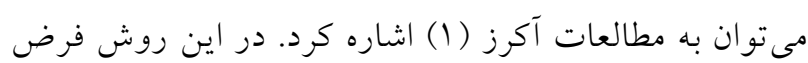
مىشود تنش برشى بين بخش هاى مختلف صفر بوده و هـيج

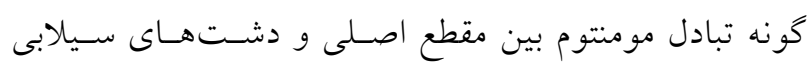

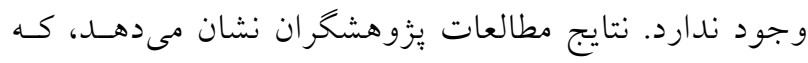
اين فرض صحيح نبوده و بههمين دليل روشهاى فوق داراى

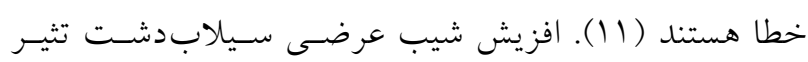
باعث تغيير تنش انتقالى بين جريان عبور از كانسال اصسلى و سيلاب دشت شده است.

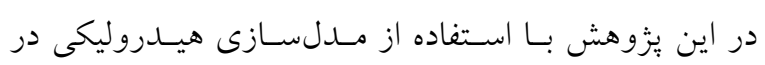

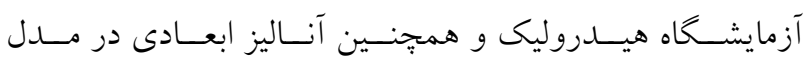

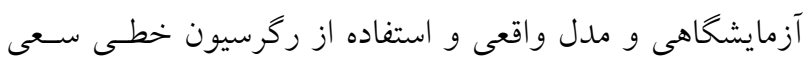

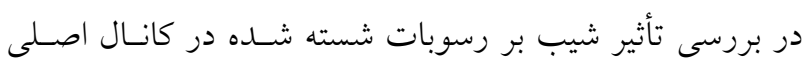
مىشود. تركيب شيبهاى طولى وعرضى بر روند آبشستخى در

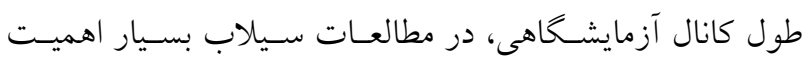
داشته و با توجه به نبود مطالعه واحد براى بررسى اين موضوع، 
خلاف روشهاى كذشته تأثير اجزاى سـرعت در جهـتهـاى

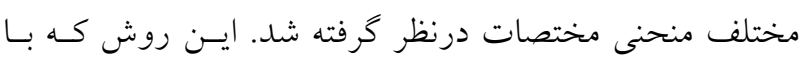

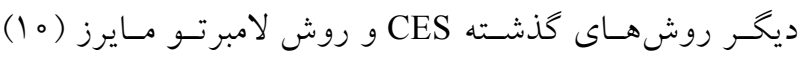

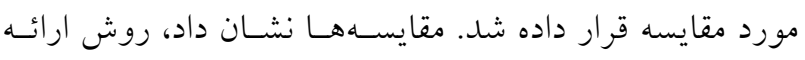

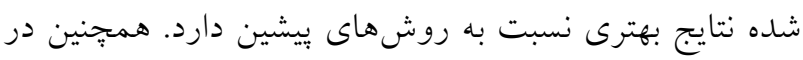

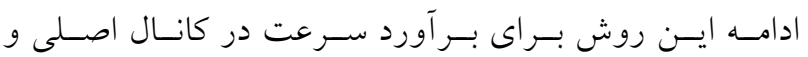

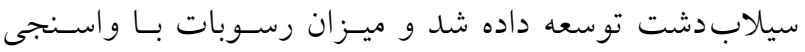

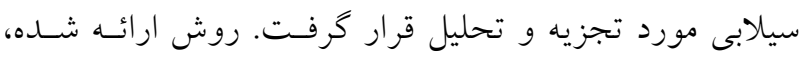

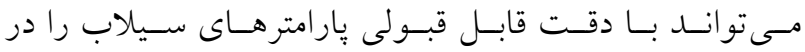
سيلابدشت و كانال اصلى تخمين بزند (ه ).

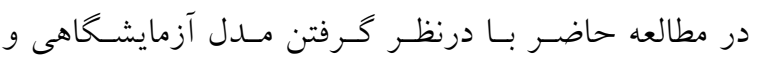
همجنين استفاده كردن از تكنيك آناليز ابعادى استفاده شــده در مطالعات ياد شده، طرح آزمايشهايى هيدروليكى براى بررسى ندي يارامتر شيب جانبى (شيب سيلابدشت) و شـيب طسولى كانـال اصلى طرحريزى شد. همجنين با درنظر كرفتن مطالعاتى در اين

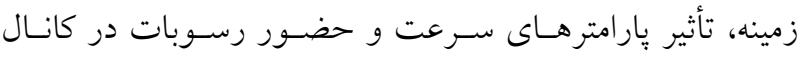

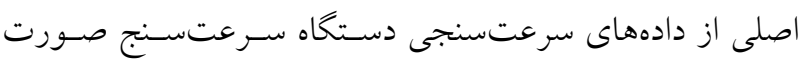

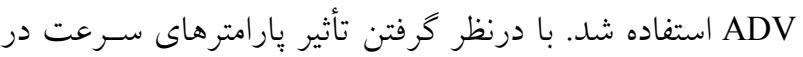
جهتهاى سه كانه منحنى مختصات، تأثير سرعت افقى بر بر ميزان

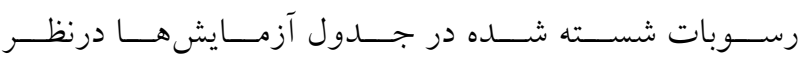
كرفته شد. بايلى (r) به بررسى تأثير يوشش كيـاهى در سـيلابدشـت

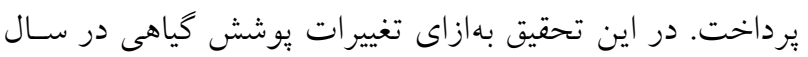

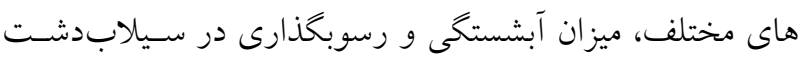

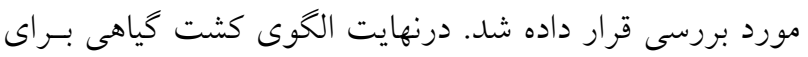
به حداقل رساندن مقدار فرسايش و شسته شدن رسـوبات ارائسه

بررسى وضعيت جريان در رودخانههاى واقعى بـا مقيـاس واقعى يكى از مسائل مورد مطالعه در زمينه سيلابدشت اسـت (Y). در اين يُزوهش رودخانهاى بهعنوان مورد يزّوهشى، بررسى ميدانى شد. بيان شد كه بهازاى تغييرات ناگهانى در مقطع جريان در امتداد رودخانه شرايط ويزهاى براى رسوبشـويى جريـان بـهـ
كَاهى، رابطهاى بر باية آناليز ابعادى براى برآورد ميـزان ارتفـاع

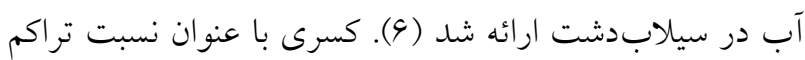

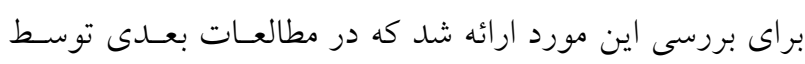

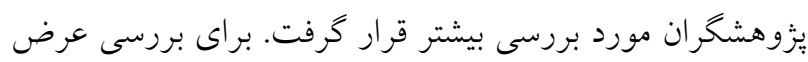

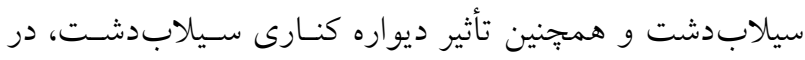

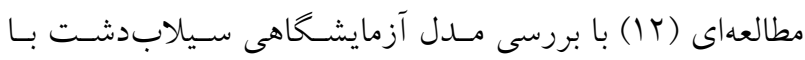

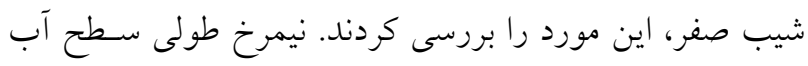

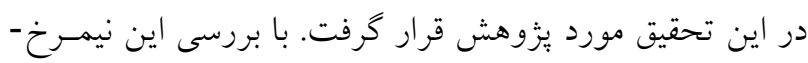

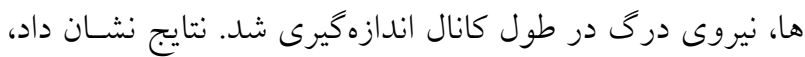
با افزايش اعداد رينولدز جريان ضريب درى يوشش كيـاهى بـهـ صورت فزايندهاى كاهش بيدا مى كند. ايسن مطلـب بيـانكر ايسن

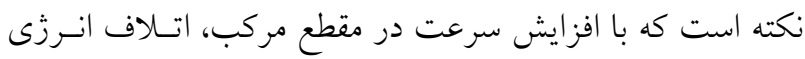
در طول كانال كاهش بيدا مى كند. بسـيارى از مطالعـات بــه بررسـى منحنسى ســنجى در

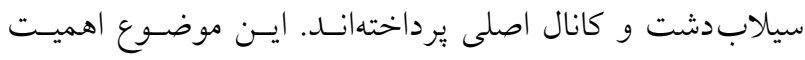

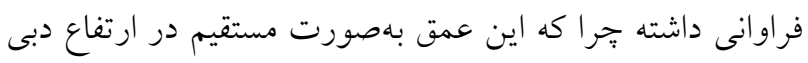

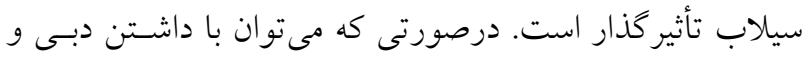

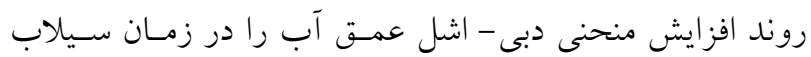
تخمين زد. مطالعات زيادى در اين زمينه يافت مىشوده از از جمله

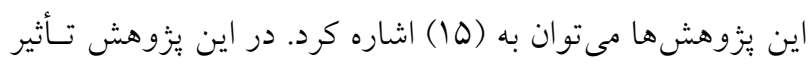

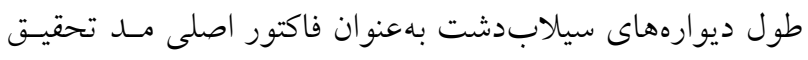

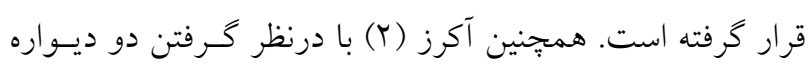

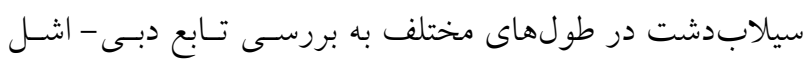

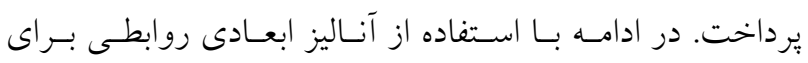

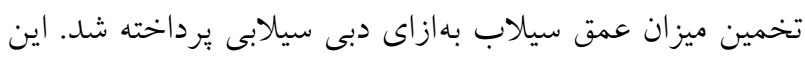

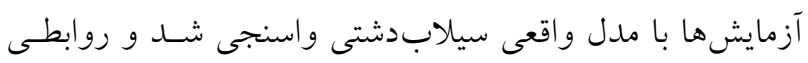

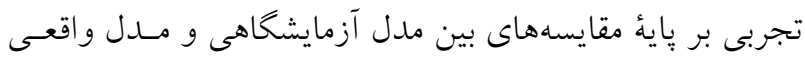

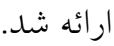

بررسى ميـزان رسـوبات شسـته شـــه در زمـان سـيلاب موضوعى است كه همـواره مـورد اهميـت بـوده اسـت. ارائسه

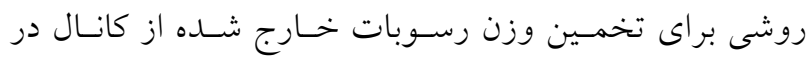

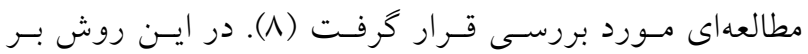


سانتى متـر و ارتفــاع ه/ متـــ انجـام كرفـت. سـاختمان فلـوم

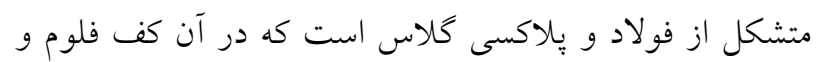

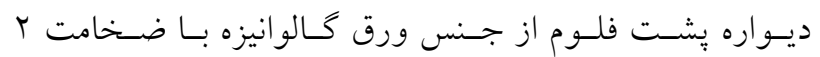

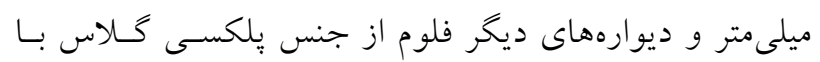

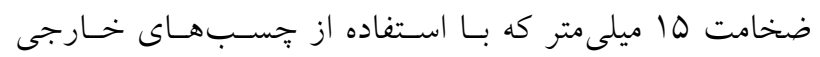

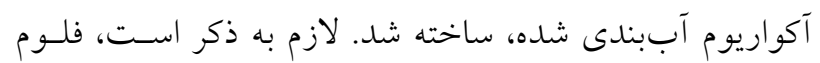
آزمايشــاهى در اسـتاندارد طبقهبندى مى شود (شكل (1).

ب) دستخاه سرعت ســنج صـوتى: تحليـل ميـدان جريـان و

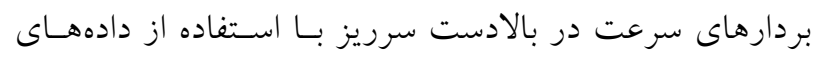

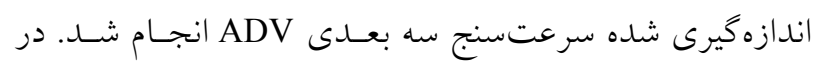

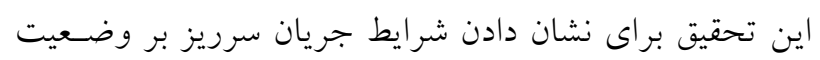

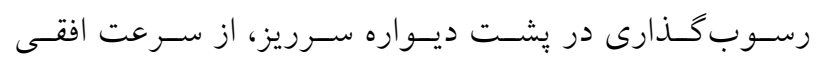

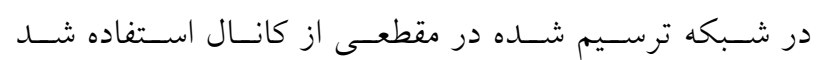

ج) ابزار تغيير شيب طولى: در طول آزمايشهـا از ابـزار تعبيـهـ

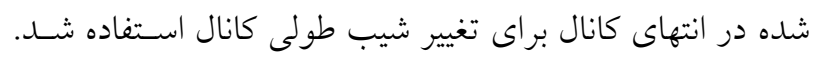

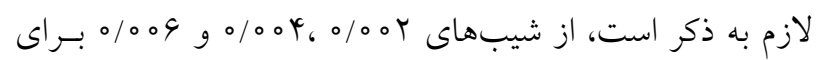

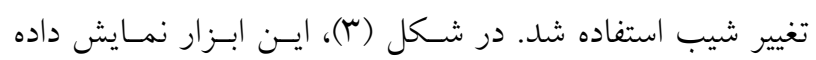

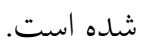

د) آناليز ابعادى: پارامترهاى فيزيكى حــاكم بــر جريـان مقــاطع مركب در رابطه (1) ارائه شده است: $\mathrm{V}_{\text {out }}=$

$\mathrm{f}\left(\mathrm{Q}_{\mathrm{f}}, \mathrm{h}_{\mathrm{o}}, \mathrm{h}_{\mathrm{s}}, \mathrm{hf}, \mathrm{S}_{\mathrm{o}}, \mathrm{S}_{\mathrm{y}}, \mathrm{b}, \mathrm{w}, \mathrm{V}, \gamma, \mu, \sigma, \rho, \mathrm{g}, \mathrm{B}, \mathrm{d}_{50}, \gamma_{\mathrm{s}}\right)$

در رابطه بالا، Q : دبى جريان، ho: عمق آب در كانال، hs ارتفاع

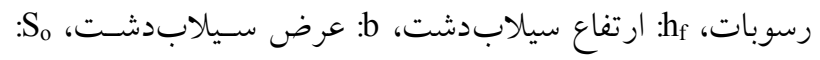

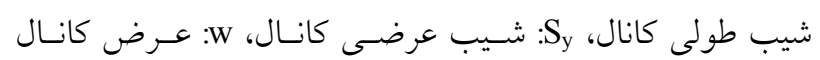

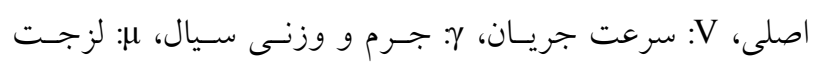

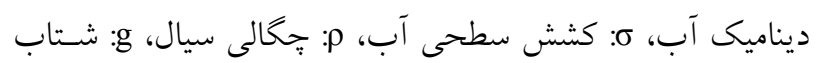

وجود خواهد آمد. يكى از عواملى كه رسوبشـويى در مقـاطع را

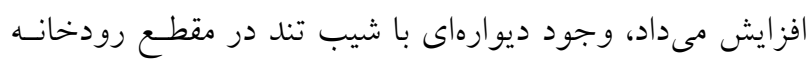

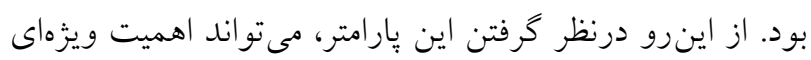

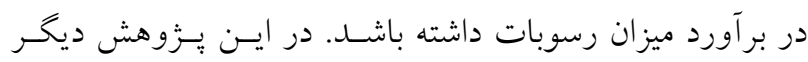

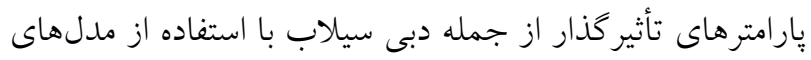
عددى، مورد بحث و يُزوهش قرار داده شد.

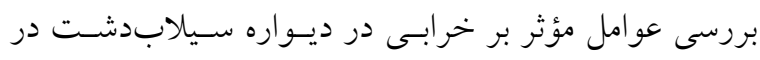

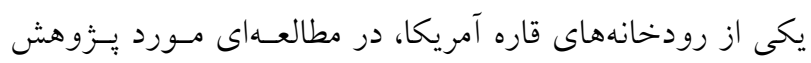

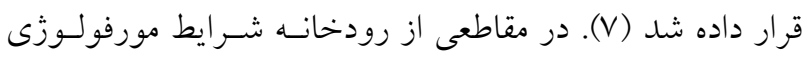

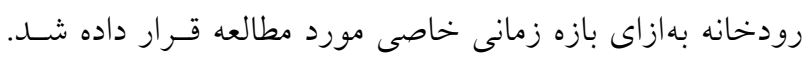

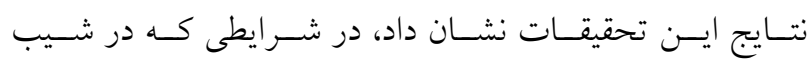
سيلاب دشت يوشش كياهى وجود داشته باشد، شـر ايط جريـان

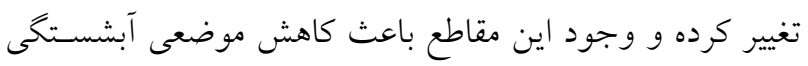

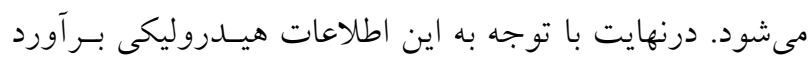

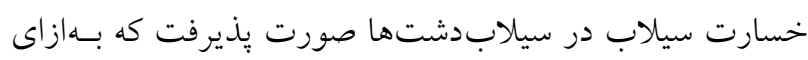
دبى سيلابهاى مختلف، ميزان خسارات محاسبه شد.

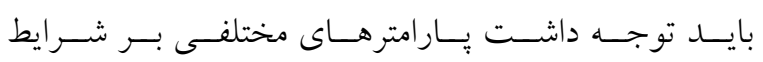

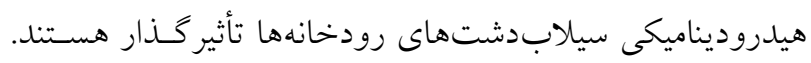

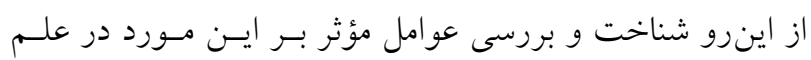

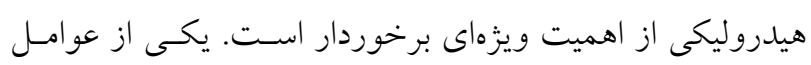

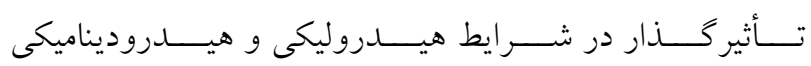
سيلابدشتها، شيب جانبى سيلابدشت است با اين اوصـاف،

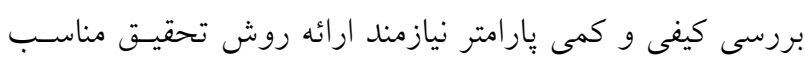

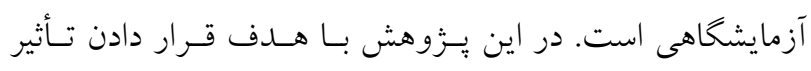

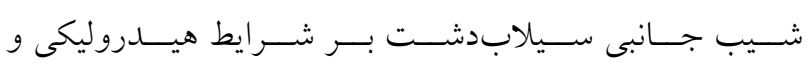

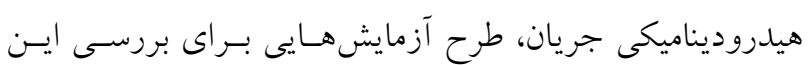

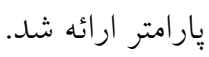

\section{مواد و روشها}

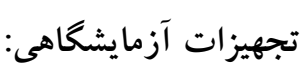

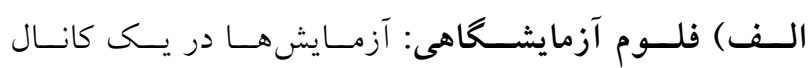

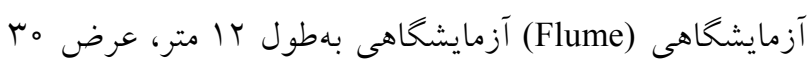




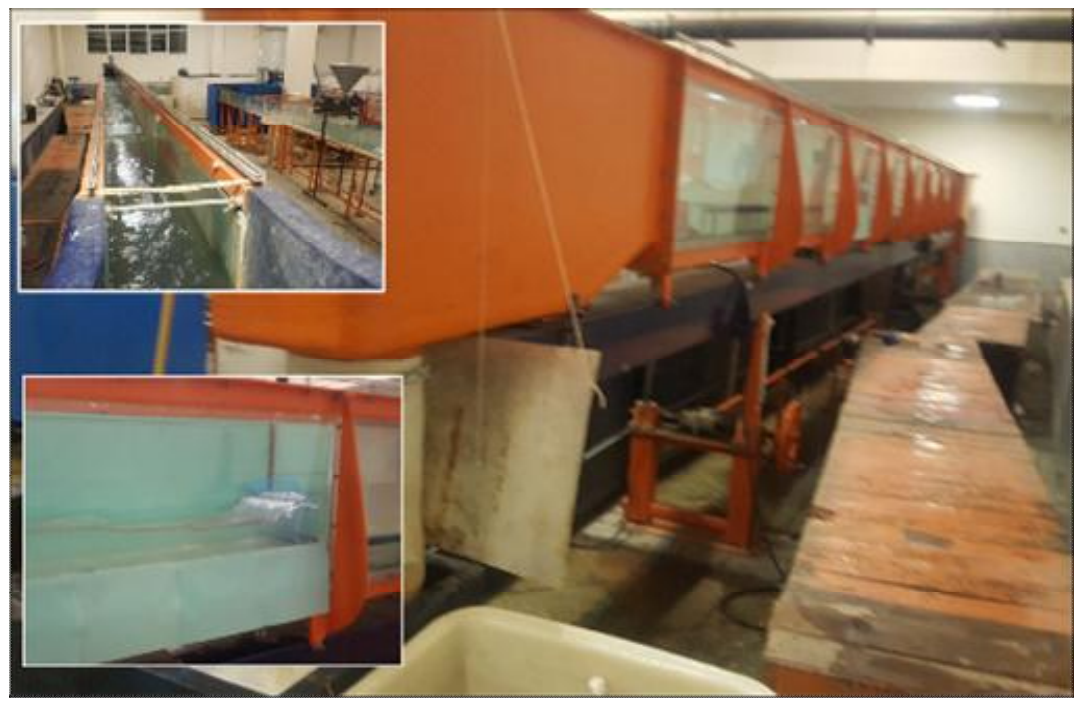

شكل 1. نمايى از زواياى مختلف كانال آزمايشحاهى

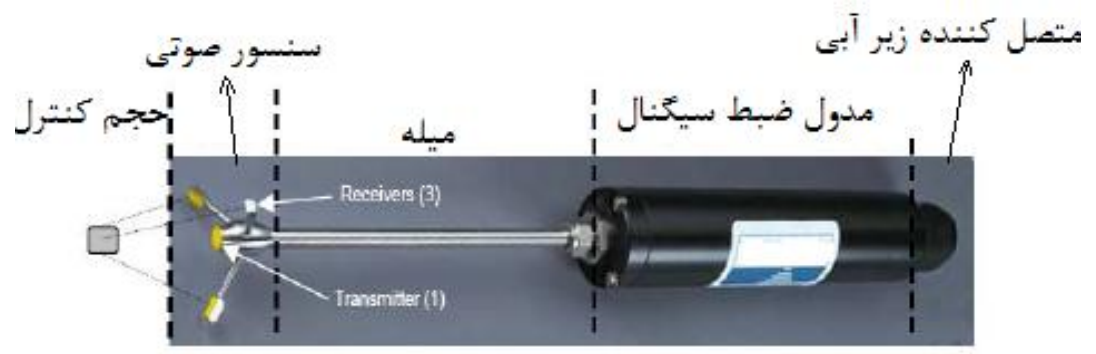

شكل r. سرعت سنج صوتى انعكاسى QY مكاهر تز

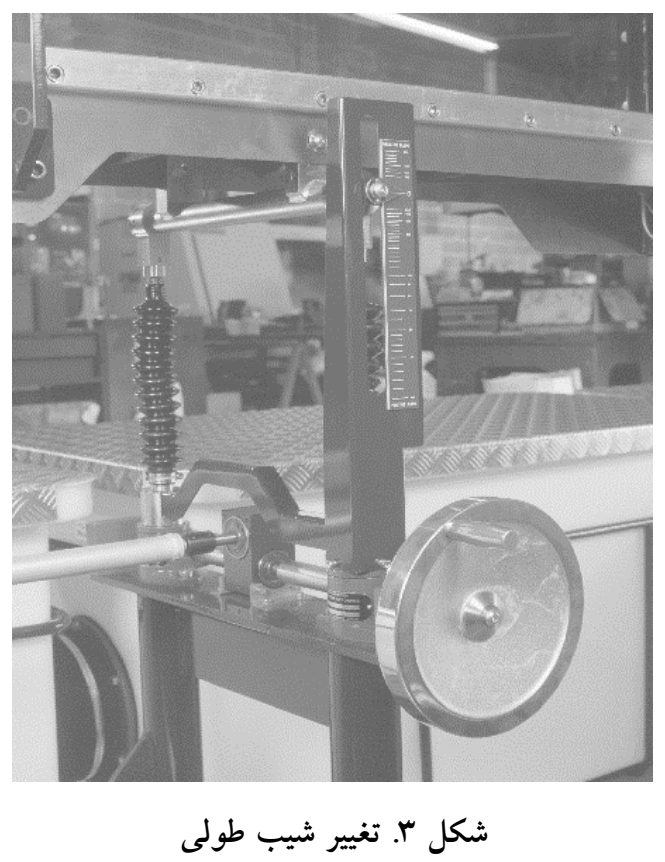


داده شده است. همجِنين، منظور از عــد فــوود وزنسى عــد است.

ه) جدول آزمايشها: براى بررسى تأثير شـيب جـانبى و شـيب

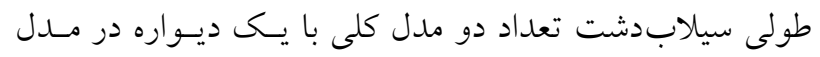

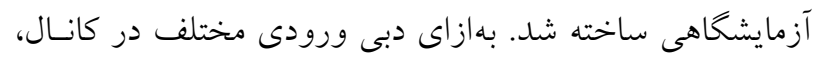

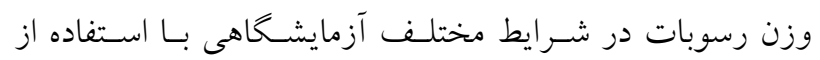

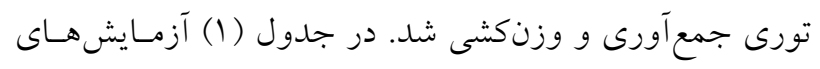

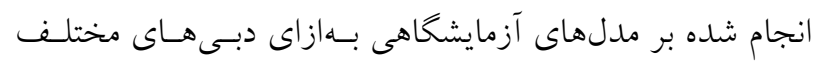

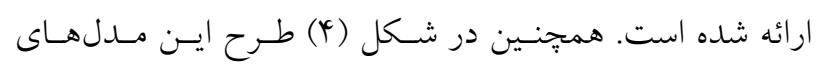

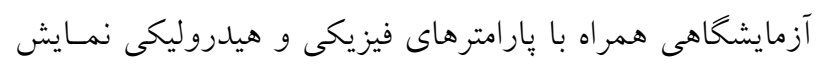

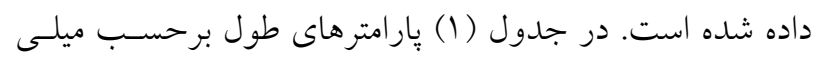

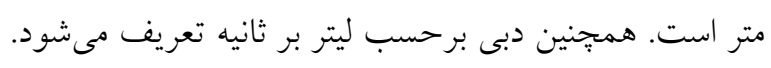

ى) آزمايشهاى مكانيك خاكى (دانهبندى): بـهمنظـور تعيسين

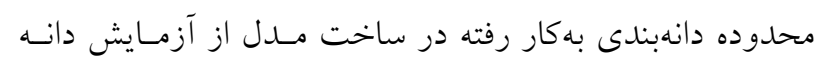
بندى با الكهاى استاندارد استفاده شد. در شكل (ه) منحنى دانه دانه دانه

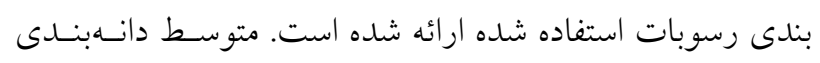

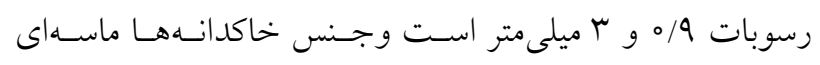

ر) اندازهگيرى سرعت: اندازهيرى سـرعت، در شـبكهبنـدى

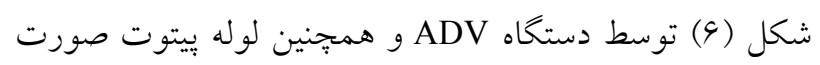

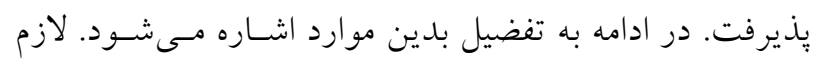

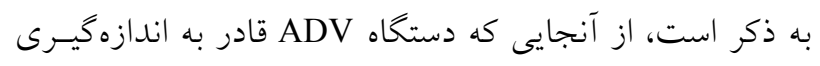

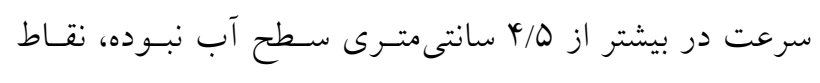

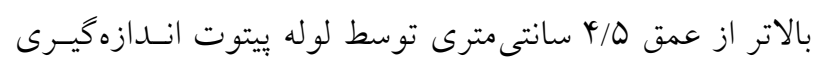

شد.

\section{نتايج و بحث}

پِ از انجام آزمايشهاى مدل آزمايشخاهى سيلابدشت، نتايج بلصورت زير مورد مقايسه قرار داده شد:
ثقل زمين ، B: عرض كل كانال ، Vs: حجــم رسـوبى از كانـال و

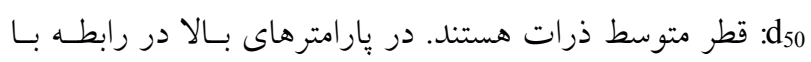

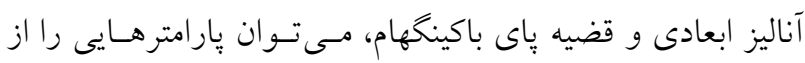

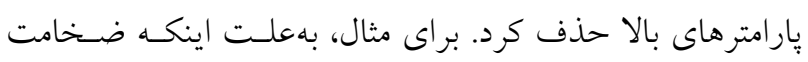

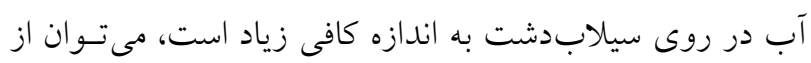

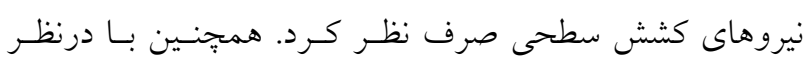

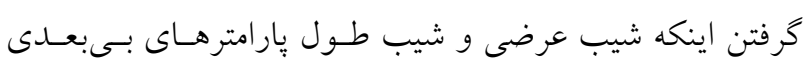

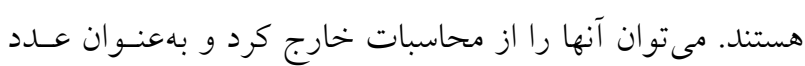

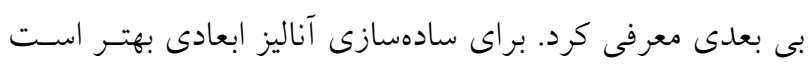

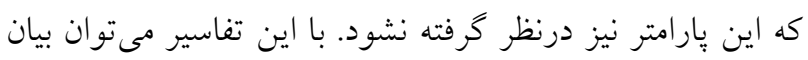
كرد كه:

$\mathrm{Vs}=\mathrm{f}\left(\mathrm{h}_{\mathrm{o}}, \mathrm{h}_{\mathrm{s}}, \mathrm{hf}, \mathrm{b}, \mathrm{w}, \mathrm{V}, \gamma, \mu, \sigma, \rho, \mathrm{g}, \mathrm{B}, \mathrm{d}_{50}\right)$

$\Pi_{1}=\mathrm{S}_{\mathrm{o}}, \Pi_{2}=\mathrm{S}_{\mathrm{y}}$

مى توان بهدو صورت پارامترهاى تكرار شونده را درنظر گرفـت.

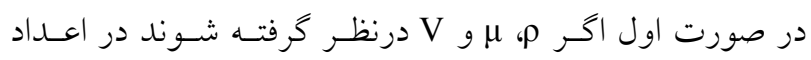

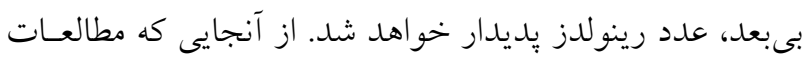

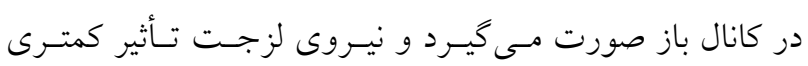

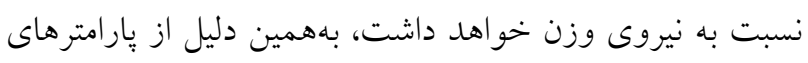
تكرار شونده بايد استفاده شود كه نيروى وزن (عدد فرود) تـأثير

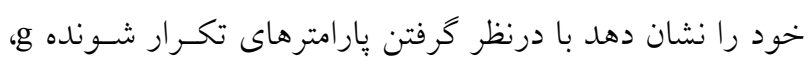

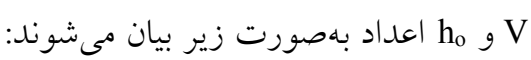
$\mathrm{Vs}=\mathrm{f}\left(\mathrm{h}_{\mathrm{o}}, \mathrm{h}_{\mathrm{s}}, \mathrm{hf}, \mathrm{b}, \mathrm{w}, \mathrm{V}, \gamma, \mu, \rho, \mathrm{g}, \mathrm{B}, \mathrm{d}_{50}, \gamma_{\mathrm{s}}\right)$

همج:جنين:

$\left[\begin{array}{ccccccccccc} & \mathrm{Vs}_{\mathrm{s}} & \mathrm{h}_{\mathrm{s}} & \mathrm{h}_{\mathrm{f}} & \mathrm{b} & \mathrm{w} & \mu & \mathrm{d}_{50} & \mathrm{~h}_{\mathrm{o}} & \mathrm{g} & \mathrm{V} \\ \mathrm{M} & 0 & 0 & 0 & 0 & 0 & 1 & 1 & 0 & 0 & 0 \\ \mathrm{~L} & 3 & 1 & 1 & 1 & 1 & -1 & 0 & 1 & 1 & 1 \\ \mathrm{~T} & 0 & 0 & 0 & 0 & 0 & -1 & 0 & 0 & -2 & -1\end{array}\right]$

$\Pi_{3}=\frac{\mathrm{h}_{\mathrm{s}}}{\mathrm{h}_{\mathrm{o}}}, \Pi_{4}=\frac{\mathrm{h}_{\mathrm{f}}}{\mathrm{h}_{\mathrm{o}}} ، \Pi_{5}=\frac{\mathrm{b}}{\mathrm{h}_{\mathrm{o}}} ، \Pi_{6}=\frac{\mathrm{d}_{50}}{\mathrm{~h}_{\mathrm{o}}}$ 。

$$
\Pi_{7}=\frac{\mathrm{w}}{\mathrm{h}_{\mathrm{o}}} \cdot \Pi_{8}=\frac{\mathrm{V}_{\mathrm{s}} \mathrm{V}}{\sqrt{\mathrm{g} h \mathrm{~h}^{3.5}}}=\frac{\mathrm{W}_{\text {out }} \mathrm{V}}{\gamma_{\mathrm{s}} \sqrt{\mathrm{g} h \mathrm{o}^{3.5}}}
$$

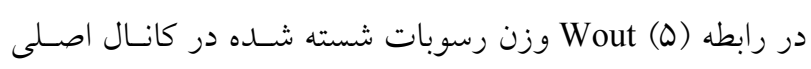

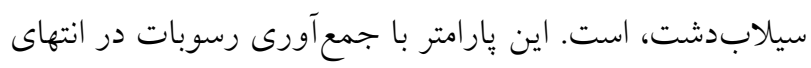

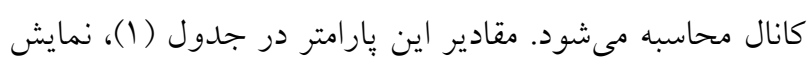


جدول ا. آزمايشهاى كانال مركب با يك ديواره سيلابدشت

\begin{tabular}{|c|c|c|c|c|c|c|c|c|c|c|c|c|c|c|c|c|c|}
\hline W(out) & ho & hf & hs & $\mathrm{d} 50$ & Sy & So & دبى & شماره & W(out) & ho & hf & hs & d50 & Sy & So & دبى & شماره \\
\hline $\mathrm{Kg}$ & $\mathrm{mm}$ & $\mathrm{mm}$ & $\mathrm{mm}$ & $\mathrm{mm}$ & & & $\mathrm{L} / \mathrm{s}$ & & $\mathrm{Kg}$ & $\mathrm{mm}$ & $\mathrm{mm}$ & $\mathrm{mm}$ & $\mathrm{mm}$ & & & & \\
\hline$V / 9 T$ & 1149 & kro & $V_{0}$ & $0 / 9$ & $\circ / 0$ & $0 / 0 \circ Y$ & $9 / 1$ & TQ & $V / I T$ & וr & Iro & Vo & $0 / 9$ & $\circ$ & O००Y & $9 / 1$ & 1 \\
\hline $1 / 09$ & 101 & $1 r_{0}$ & $V_{0}$ & $0 / 9$ & $\circ / 0$ & $0 / 0 \circ Y$ & $9 / r$ & TQ & $1 / \pi 9$ & IFr & $1 r_{0}$ & $V_{0}$ & $0 / 9$ & 。 & O/O० & $9 / r$ & r \\
\hline$r / \mu_{0}$ & 194 & Iro & Vo & $0 / 9$ & $\circ / 0$ & $0 / 0 \circ Y$ & $10 / V$ & TV & $Y / \circ \circ$ & TYG & Iro & Vo & $0 / 9$ & $\circ$ & $\circ / 0 \circ Y$ & $10 / \mathrm{V}$ & $r$ \\
\hline I/VG & $|V|$ & Kro & $v_{0}$ & $0 / 9$ & $\circ / 0$ & \%०OY & $11 / 1$ & rA & $1 / 09$ & 109 & Iro & $v_{0}$ & $0 / 9$ & 。 & O/O०Y & $11 / 1$ & k \\
\hline$r / 90$ & $I \wedge V$ & $1 r_{0}$ & $V_{0}$ & $r / 。$ & $\circ / 0$ & $0 / 0 \circ Y$ & $4 / 1$ & rq & $r / 10$ & Irk & $1 r_{0}$ & $V_{0}$ & $r / 。$ & 。 & O/O०Y & $9 / 1$ & 0 \\
\hline$r / 09$ & 195 & $1 r_{0}$ & $V_{0}$ & $r / 。$ & $\circ / 0$ & $0 / 0 \circ Y$ & $9 / r$ & $r_{0}$ & $r / 10$ & IFr & $M O$ & $V_{0}$ & $\mu / 。$ & $\circ$ & $\circ / 0 \circ Y$ & $9 / r$ & 9 \\
\hline$\varphi / \Delta \circ$ & $|V|$ & $1 r_{0}$ & $V_{0}$ & $r / 。$ & $\circ / 0$ & $0 / 0 \circ Y$ & $10 / V$ & rI & $\varphi / \circ \Delta$ & 109 & $1 r_{0}$ & $V_{0}$ & $r / 。$ & $\circ$ & $\circ / 0 \circ Y$ & $10 / \mathrm{V}$ & V \\
\hline $0 / 9 \mu$ & 111 & $1 r_{0}$ & $V_{0}$ & $r / 。$ & $\circ / 0$ & $0 / 0 \circ Y$ & $11 / 1$ & rT & Q/Dr & 194 & $1 r_{0}$ & $V_{0}$ & $\mu / 。$ & 。 & $\circ / 0 \circ Y$ & $11 / 1$ & $\wedge$ \\
\hline $1 / 94$ & 101 & $1 r_{0}$ & $V_{0}$ & $0 / 9$ & $\circ / 0$ & $0 / 0 \circ Y^{4}$ & $9 / 1$ & r & $1 / 1 \pi$ & 149 & $K_{0}$ & Vo & $0 / 9$ & $\circ$ & ०/०० & $9 / 1$ & 9 \\
\hline$r / 94$ & $10 F$ & $1 r_{0}$ & $V_{0}$ & $\circ / 9$ & $\circ / 0$ & $0 / 0 \circ Y^{f}$ & $9 / \pi$ & ry & $r / \Gamma \mid$ & $1 \pi x$ & $M O$ & $V_{0}$ & $0 / 9$ & $\circ$ & $\circ / 0 \circ Y^{f}$ & $9 / r$ & 10 \\
\hline$r / 9 \Lambda$ & 194 & $1 r_{0}$ & $V_{0}$ & $\circ / 9$ & $\circ / 0$ & $0 / 0 \circ Y^{f}$ & $10 / \mathrm{V}$ & ro & $r / \uparrow Q$ & IFr & $1 r_{0}$ & $V_{0}$ & $0 / 9$ & $\circ$ & ०/०० f & $10 / \mathrm{V}$ & 11 \\
\hline$Y / V T$ & $10 F$ & $1 r_{0}$ & $V_{0}$ & $0 / 9$ & $\circ / 0$ & $0 / 0 \circ \varphi^{t}$ & $11 / 1$ & re & $\psi / V_{0}$ & 149 & $r_{0}$ & $V_{0}$ & $0 / 9$ & $\circ$ & $0 / 0 \circ \psi^{f}$ & $11 / 1$ & Ir \\
\hline$r / r$ & Iru & kro & $V_{0}$ & $r / 。$ & $\circ / 0$ & $0 / 0 \circ Y^{k}$ & $9 / 1$ & rv & $r / \wedge 9$ & $1 \% 4$ & $K_{0}$ & $v_{0}$ & $r / 。$ & 。 & ०/०० & $9 / 1$ & $1 r$ \\
\hline $4 / \wedge q$ & lkt & $1 r_{0}$ & $V_{0}$ & $r / 。$ & $\circ / 0$ & $0 / 0 \circ Y^{Y}$ & $9 / T$ & rی & $4 / 0 q$ & 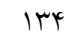 & $1 r_{0}$ & $v_{0}$ & $r / 。$ & 。 & ०/००४ & $9 / r$ & 14 \\
\hline $0 / 99$ & 190 & Iro & Vo & $r / 。$ & $\circ / 0$ & $0 / 0 \circ Y^{f}$ & $10 / V$ & rq & Q/DQ & 140 & $1 r_{0}$ & Vo & $r / 。$ & $\circ$ & ०/०० F & $10 / \mathrm{V}$ & 10 \\
\hline$V / 19$ & 199 & $1 r_{0}$ & $V_{0}$ & $r / 。$ & $\circ / 0$ & $0 / 0 \circ Y^{Y}$ & $11 / 1$ & $r_{0}$ & $V / 1 \circ$ & 149 & $M O$ & $V_{0}$ & $\mu / 。$ & $\circ$ & ०/०० F & $11 / 1$ & 19 \\
\hline$r / 19$ & 140 & $1 r_{0}$ & $V_{0}$ & $0 / 9$ & $\circ / 0$ & $0 / 004$ & $9 / 1$ & 41 & $r / \circ \circ$ & 119,0 & $1 r_{0}$ & $V_{0}$ & $0 / 9$ & $\circ$ & $0 / 004$ & $9 / 1$ & IV \\
\hline $9 / 09$ & $|4|$ & $1 r_{0}$ & $V_{0}$ & $0 / 9$ & $\circ / 0$ & 01004 & $9 / r$ & kr & $0 / 09$ & ITO & $M O$ & $V_{0}$ & $0 / 9$ & $\circ$ & $0 / 004$ & $9 / r$ & 11 \\
\hline$\Lambda / \circ \Lambda$ & IrV & $1 r_{0}$ & $V_{0}$ & $0 / 9$ & $\circ / 0$ & 01004 & $10 / V$ & kr & $\mathrm{V} / \mathrm{\Lambda}$ & $1 \pi 0$ & $M O$ & $V_{0}$ & $0 / 9$ & $\circ$ & $0 / 004$ & $10 / V$ & 19 \\
\hline N/rT & 179 & $1 r_{0}$ & $V_{0}$ & $0 / 9$ & $\circ / 0$ & $0 / 004$ & $11 / 1$ & $k y$ & $N / K Y$ & 148 & $1 r_{0}$ & $V_{0}$ & $0 / 9$ & $\circ$ & 01004 & $11 / 1$ & $r_{0}$ \\
\hline$r / \Gamma \wedge$ & 100 & $1 r_{0}$ & $V_{0}$ & $r / 。$ & $\circ / 0$ & 01004 & $9 / 1$ & id & $1 / 11$ & 119,0 & Iro & $V_{0}$ & $r / 。$ & $\circ$ & $0 / 004$ & $9 / 1$ & rI \\
\hline$Y / T Q$ & 149 & $1 r_{0}$ & $V_{0}$ & $\mu / 。$ & $\circ / 0$ & 01004 & $9 / T$ & 49 & $\mu / \mu \Delta$ & iro & $1 r_{0}$ & $V_{0}$ & $r / 。$ & $\circ$ & $0 / 009$ & $9 / r$ & rr \\
\hline $\mathrm{V} / \mathrm{OA}$ & 109 & $1 r_{0}$ & $V_{0}$ & $\mu / 。$ & $\circ / 0$ & 01004 & $10 / V$ & qV & $\mathrm{V} / \mathrm{Ir}$ & 149 & Iro & $V_{0}$ & $r / 。$ & $\circ$ & 01004 & $10 / \mathrm{V}$ & $r^{\mu}$ \\
\hline $4 / 1 r$ & $1 k^{k+}$ & Kro & V。 & $\mu / 。$ & $\circ / \Delta V$ & 01004 & $11 / 1$ & $\psi \wedge$ & $r / \mu r$ & ITO & Kro & V。 & $r / 0$ & 。 & 004 & $11 / 1$ & $Y^{k}$ \\
\hline
\end{tabular}

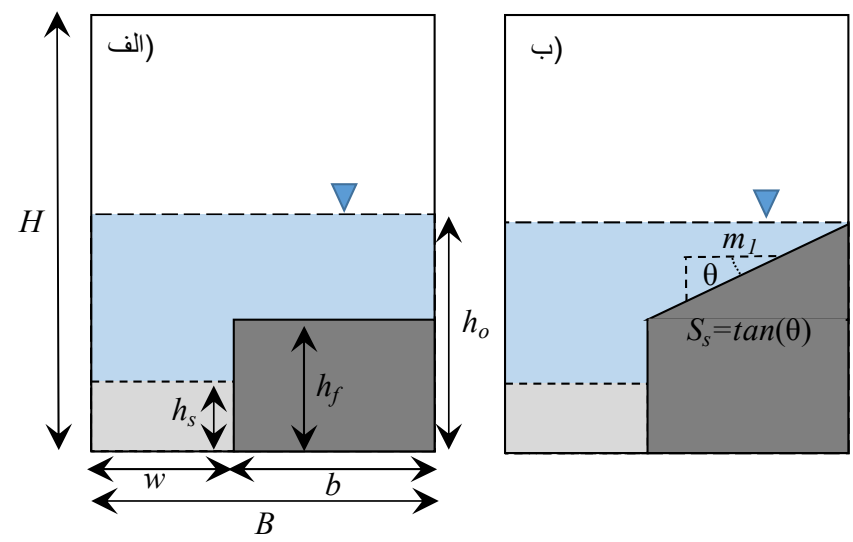

شكل f. مدلهاى آزمايشحاهى كانال مركب: الف) شيب جانبى صفر و ب) شيب جانبى 10ه 


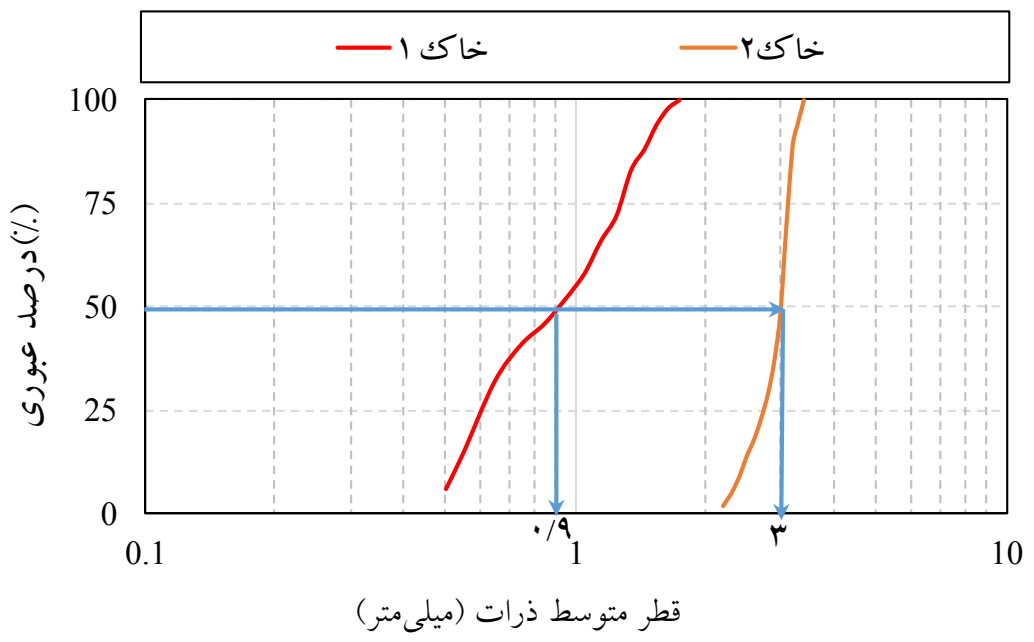

شكل ه. دانهبندى خاكهاى استفاده شده در مدلها (رنكى در نسخه الكترونيكى)

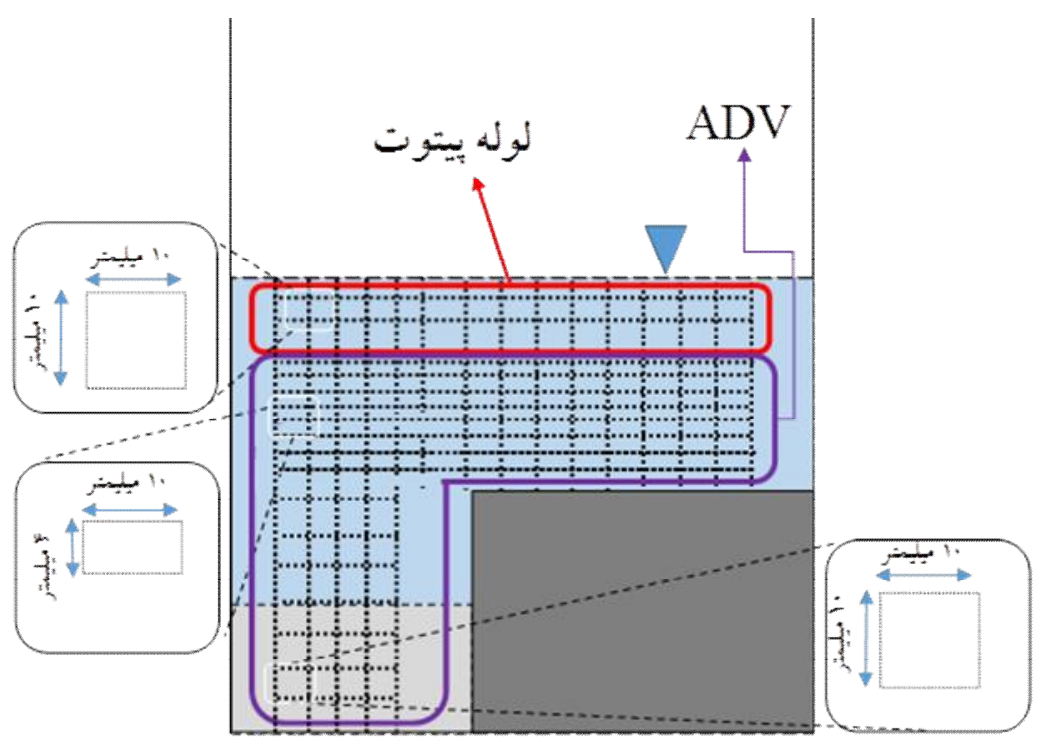

شكل 9. شبكدبندى كانال براى اندازهيرى سرعت (رنخى در نسخه الكترونيكى)

در دبى 11/ ليتر بـر ثانيسه رخ خواهـــ داد. مقايسـهــاى اوليـه بيانگر اين مطلب است، كه با افزايش دبى و شيب طولى افزايش

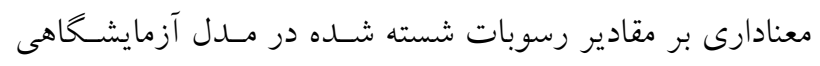

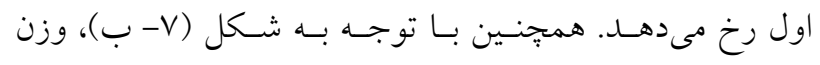
رسوبات بهازاى دبى و ديخر يارامترهاى هيدروليكى ترسيم شده است. در مدل دوم (شيب طولى بدنه سيلابدشت ه/ه)، نتـايج نشان مىدهد، كمترين مقدار شسته شده در اين مـدل در زمـانى

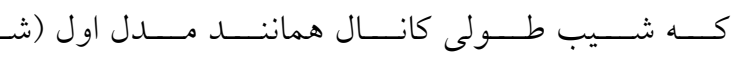

تــأثير دبــى بـــر وزن رســوبات شســـه شــده: در شــكل (V- الف)، وزن رسوبات بهازاى دبى ترسيم شده است. در مدل اول (شيب طولى بدنه سيلابدشت صفر)، نتايج نشان مىدهـد، كمترين مقدار شسته شده در اين ملدل در زمانى كه شيب طـولى

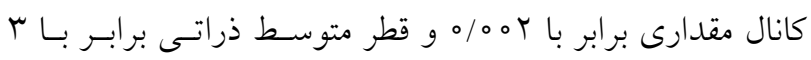
ميلىمتر در دبى /4 ليتر بر ثانيه رخ مسىهــد. در همـين حسال،

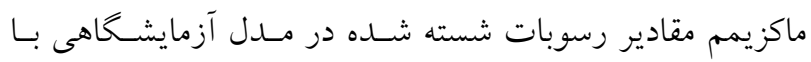
شيب طولى 9ه ٪/ و قطر متوسط ذراتى برابر بـا 9/ه ميلى متـر 


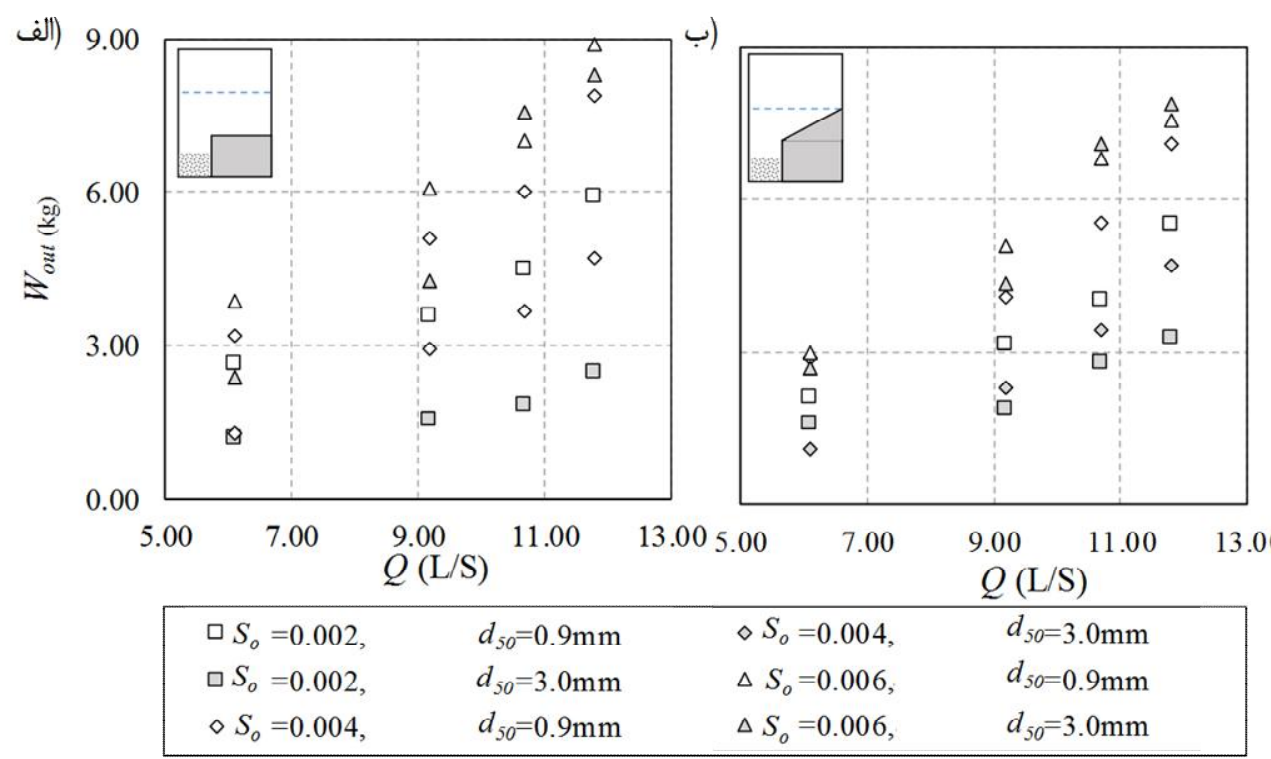

شكل V. تأثير افزايش دبى بر وزن رسوبات شستهده: الف) مدل كانال مركب با شيب جانبى صفر و ب) كانال مركب با شيب جانبى 10/
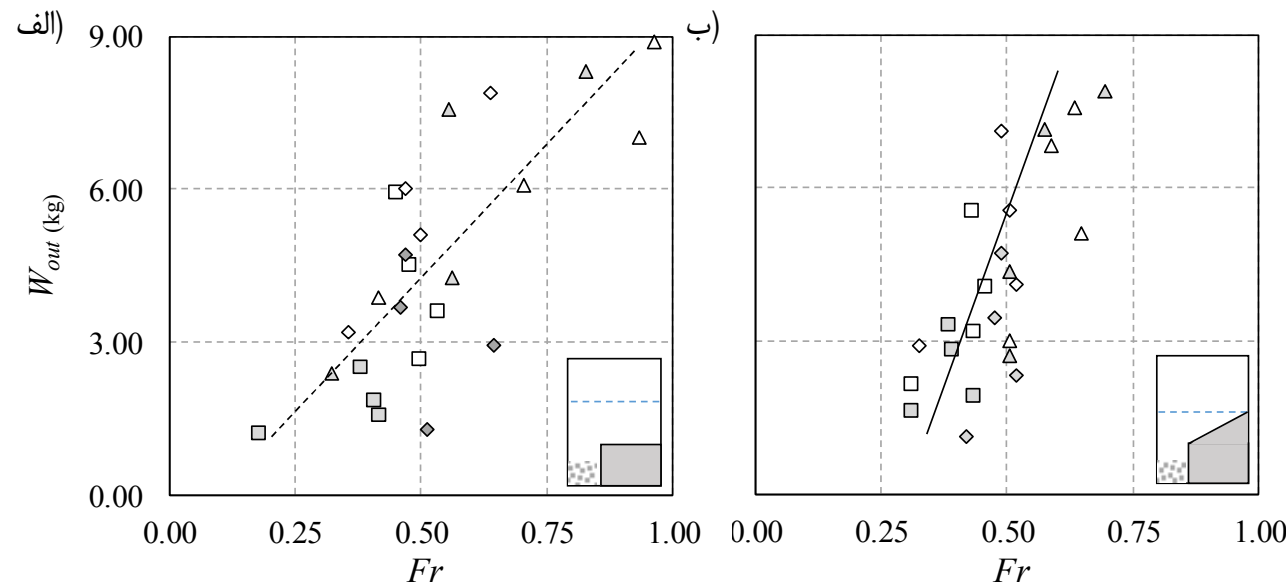

\begin{tabular}{|llll|}
\hline$\square S_{o}=0.002$ & $d_{50}=0.9 \mathrm{~mm}$ & $\diamond S_{o}=0.004$ & $d_{50}=3.0 \mathrm{~mm}$ \\
$\square S_{o}=0.002$ & $d_{50}=3.0 \mathrm{~mm}$ & $\Delta S_{o}=0.006$ & $d_{50}=0.9 \mathrm{~mm}$ \\
$\diamond S_{o}=0.004$, & $d_{50}=0.9 \mathrm{~mm}$ & $\Delta S_{o}=0.006$, & $d_{50}=3.0 \mathrm{~mm}$
\end{tabular}

شكل ^ تأثير عدد فرود بر وزن رسوبات شسته شده: الف) مدل كانال مركب با شيب جانبى صفر و ب) كانال مركب با شيب جانبى /ه

اينرو براى بررسى اين دو بارامتر در ابعاد بزرگتر از عدد فرود جريان و همختنين شيب طولى كانال براى مقايسهها استفاده شد.

تأثير عدد فرود جريان بر ميزان حمل رسوبات: در شكل (^)، مقادير وزن رسوبات شسته شده در كانـال و عــد فــرود بــراى

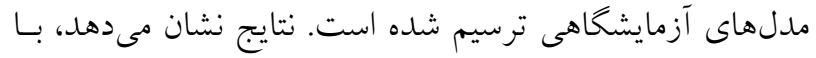

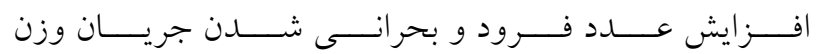

عرضى سـيلابدشـت ه/ه)، مقــارى برابـر بـا به / و قطـر

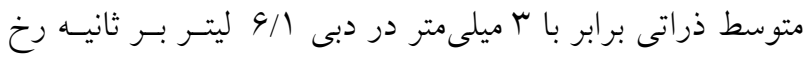
مى دهد. در همين حال، ماكزيمم مقادير رسوبات شسته شــده در

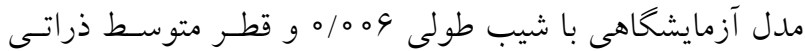

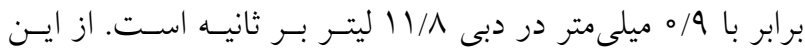

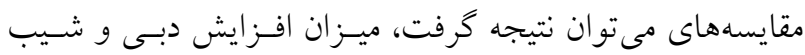

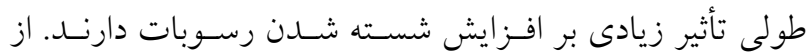




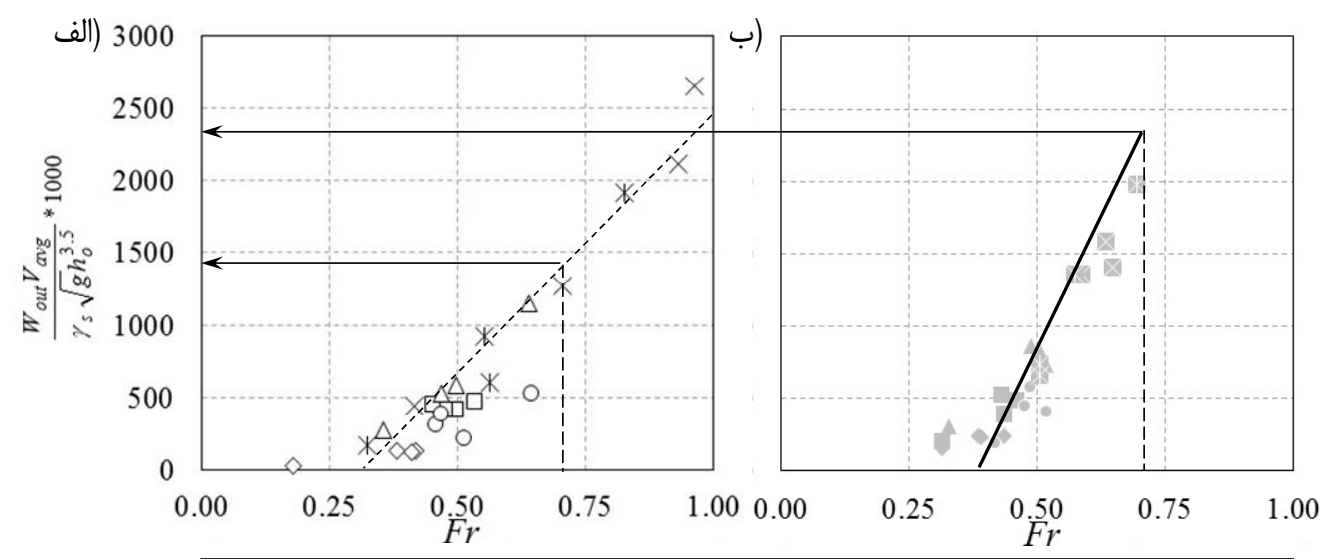

$\square S_{o}=0.002, S_{y}=0, d_{50}=0.9 \mathrm{~mm}$

$\diamond S_{o}=0.002, S_{y}=0, d_{50}=3.0 \mathrm{~mm}$

$\triangle S_{o}=0.004, S_{y}=0, d_{50}=0.9 \mathrm{~mm}$

$\circ S_{o}=0.004, S_{y}=0, d_{50}=3.0 \mathrm{~mm}$

$\times S_{o}=0.006, S_{y}=0, d_{50}=0.9 \mathrm{~mm}$

$* S_{o}=0.006, S_{v}=0, d_{50}=3.0 \mathrm{~mm}$

$S_{o}=0.002, S_{y}=0.50, d_{50}=0.9 \mathrm{~mm}$

- $S_{o}=0.002, S_{y}=0.50, d_{50}=3.0 \mathrm{~mm}$

$\triangle S_{o}=0.004, S_{y}=0.50, d_{50}=0.9 \mathrm{~mm}$

- $S_{o}=0.004, S_{y}=0.50, d_{50}=3.0 \mathrm{~mm}$

$\triangle S_{o}=0.006, S_{y}=0.50, d_{50}=0.9 \mathrm{~mm}$

$S_{0}=0.006, S_{y}=0.50, d_{50}=3.0 \mathrm{~mm}$

شكل 9.

شسته شده ، افزايش بييدا كند. با اين اوصـاف، افـزايش ميـزان رسوبات شده بهازاى عمق ثابت باعث افزايش كسر عدد فرود

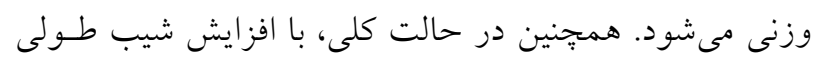

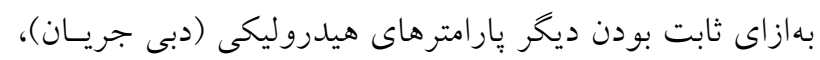

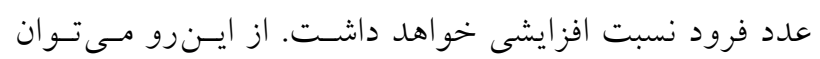

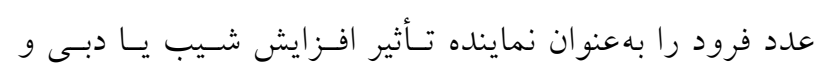

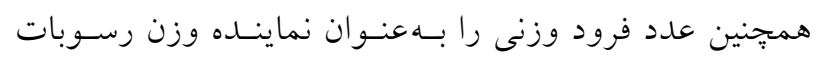

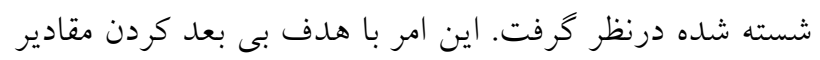

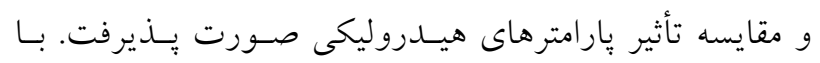

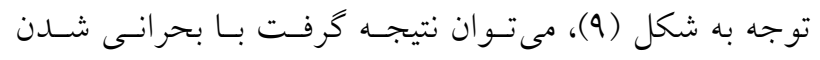

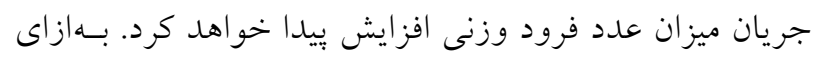

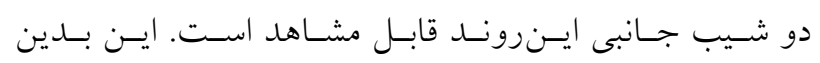
معناست، روند شسته شدن رسوبات با بحر انى تر شدن جريان

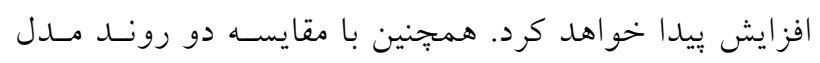

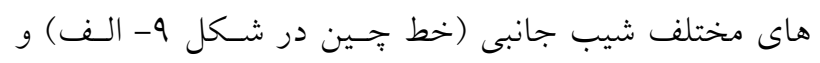

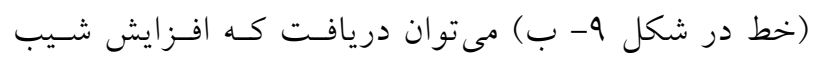
جانبى باعث افزايش عدد فرود نسبى در يكى عدد فرود شود

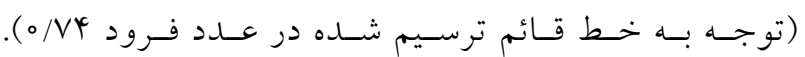

رسوبات اندازهگيرى شده در انتهاى كانال افزايش بيدا مسىكنـد.

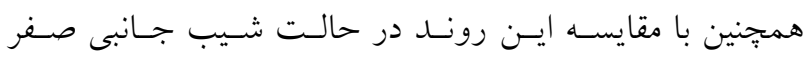

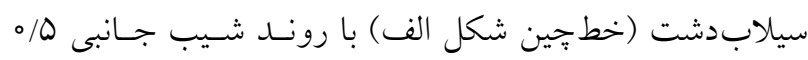

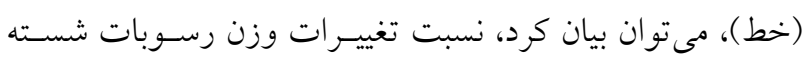

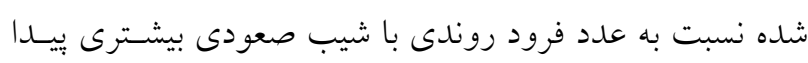

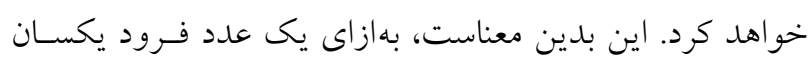

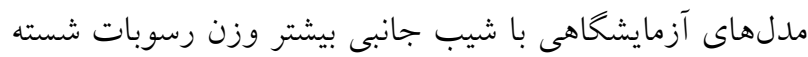

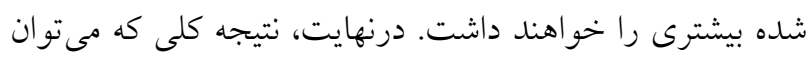

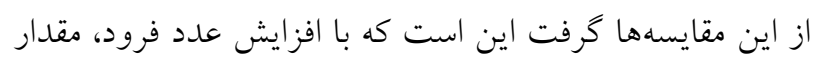
وزن رسوبات شسته افزايش ييدا خواهد كرد.

فرود وزنى: براى بررسى بىبعـد بــارامترهـاى هيـدروليكى و

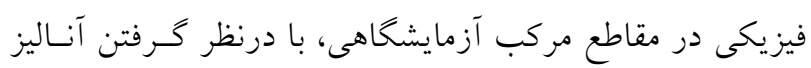

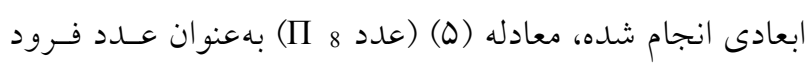

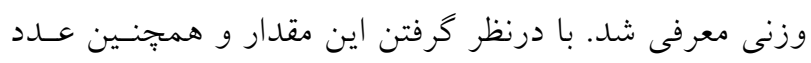

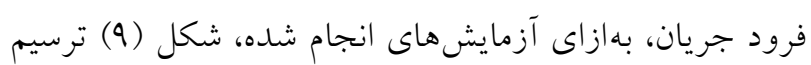

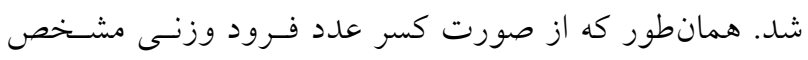

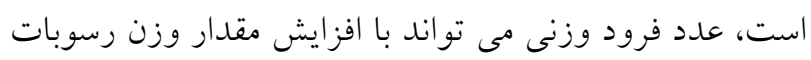




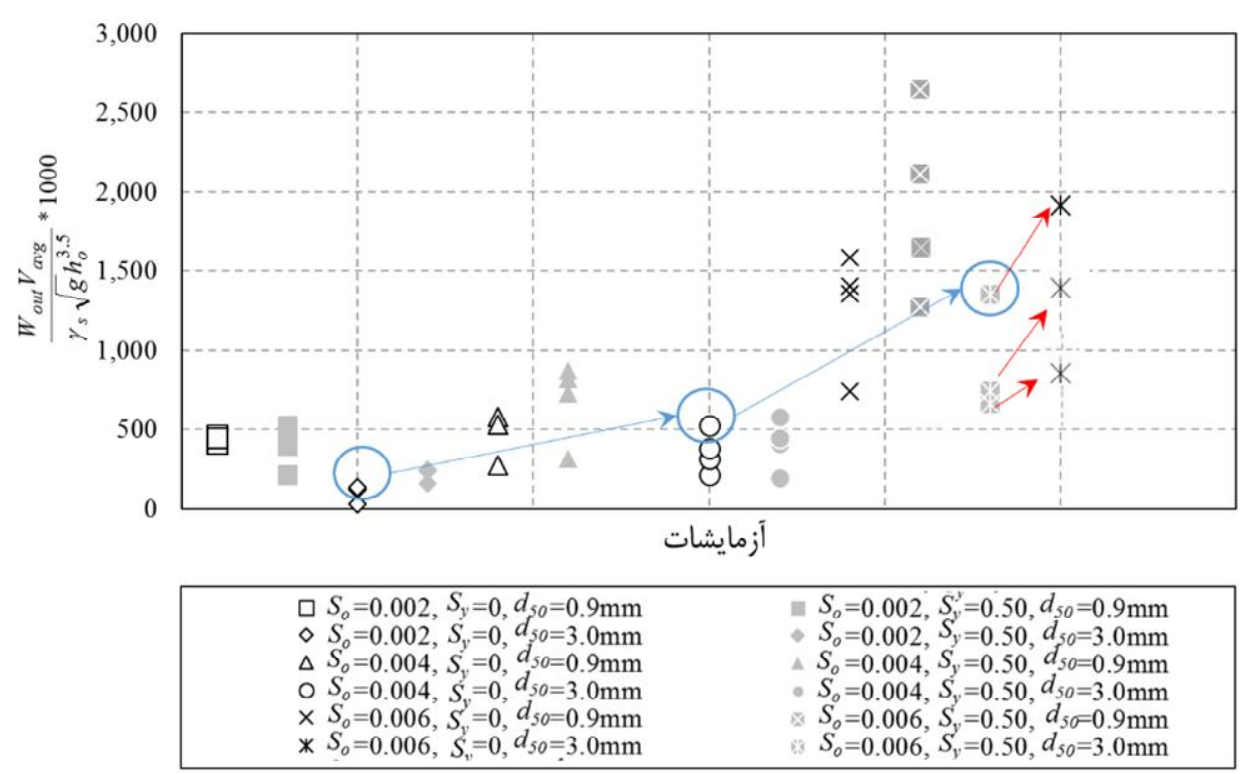

شكل ه ا. روند تغييرات فرود وزنى در مقابل شيب جانبى (رنغى در نسخه الكترونيكى)

درصورتى كه اخر آزمايشهايى با قطر، دبسى و شـيب طـولى

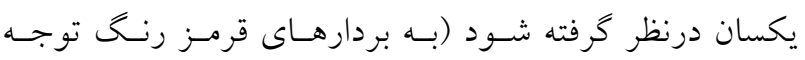
شود)، افزايش ميزان فرود وزنى كمترى نسبت به سطح مقايسه

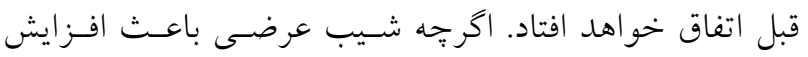
آبشستخى در كانال اصلى سيلابدشت مى شود. اما مقايسـهـهـا

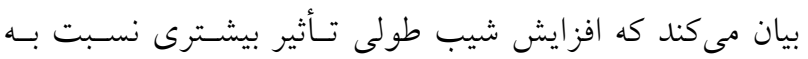
افزايش شيب عرضى داشته است. بيشبينى مى شود كه افزايش شيب طولى كانال باعث تغيير يروفيـل قـائم سـرعت افقى در مقاطع مختلف سيلابدشت و كانال اصلى مى شود. در ادامه به اين مطلب به تفضيل اشاره خواهد شد. درنهايت، رونـــ كلى لـ تغييرات عدد فرود نشان داد، با افزايش عدد فرود، ميزان عـدد فرود وزنى نيز افزايش بيدا خواهد كرد.

بررسى تغييرات سـرعت: در طـول آزمـايشهـا، بـهازاى دبسى

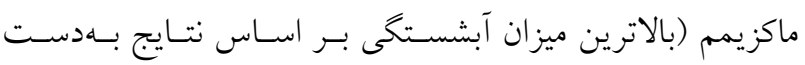

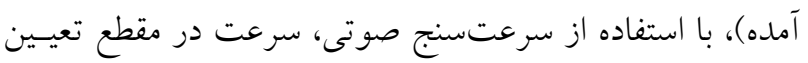
شده در شكل(9)، (اين مقطع در فاصله 9 مترى از ابتداى كانـال سترعال

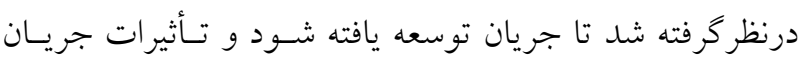

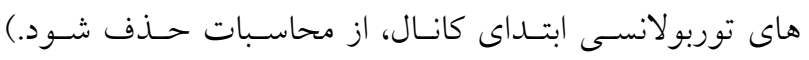

ايسن مطلـب بيـانكر آن اســت كــه افـزايش شــيب جـانبى

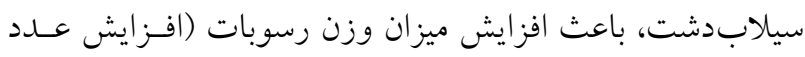
فرود وزنى) مىشود.

تأثير شيب عرضى و طولى: براى بررسى تأثير شـيب عرضى

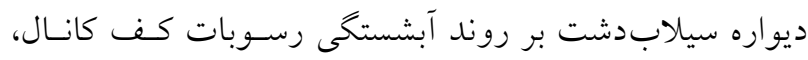
شكل (م (1) ترسيم شد. همانطور كه قابل مشـاهده اسـت، در

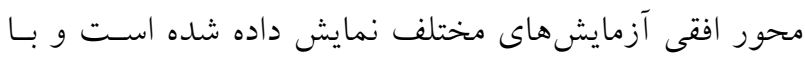

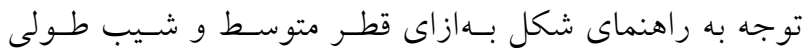

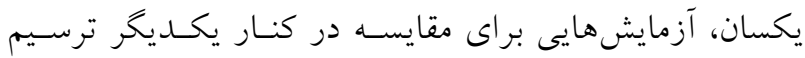
شدند. مقايسهها نشان مىدهد، با افزايش شيب طـولى ميـزان فرود وزنى بهصورت افزايش تغيير مى كند. همجنين بايد توجه

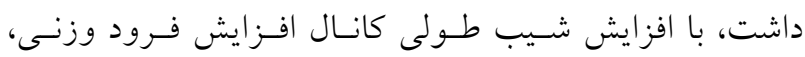

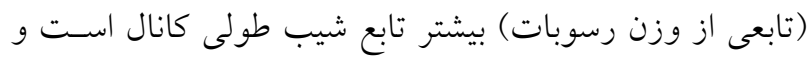

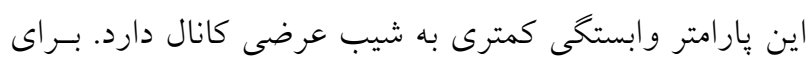

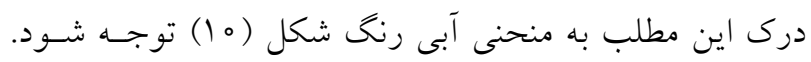

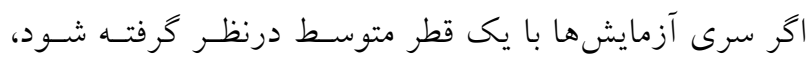
افزايش شيب طولى بهمراتب تأثير بيشترى در بالا بردن مقادير

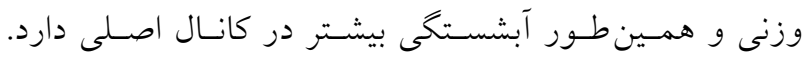



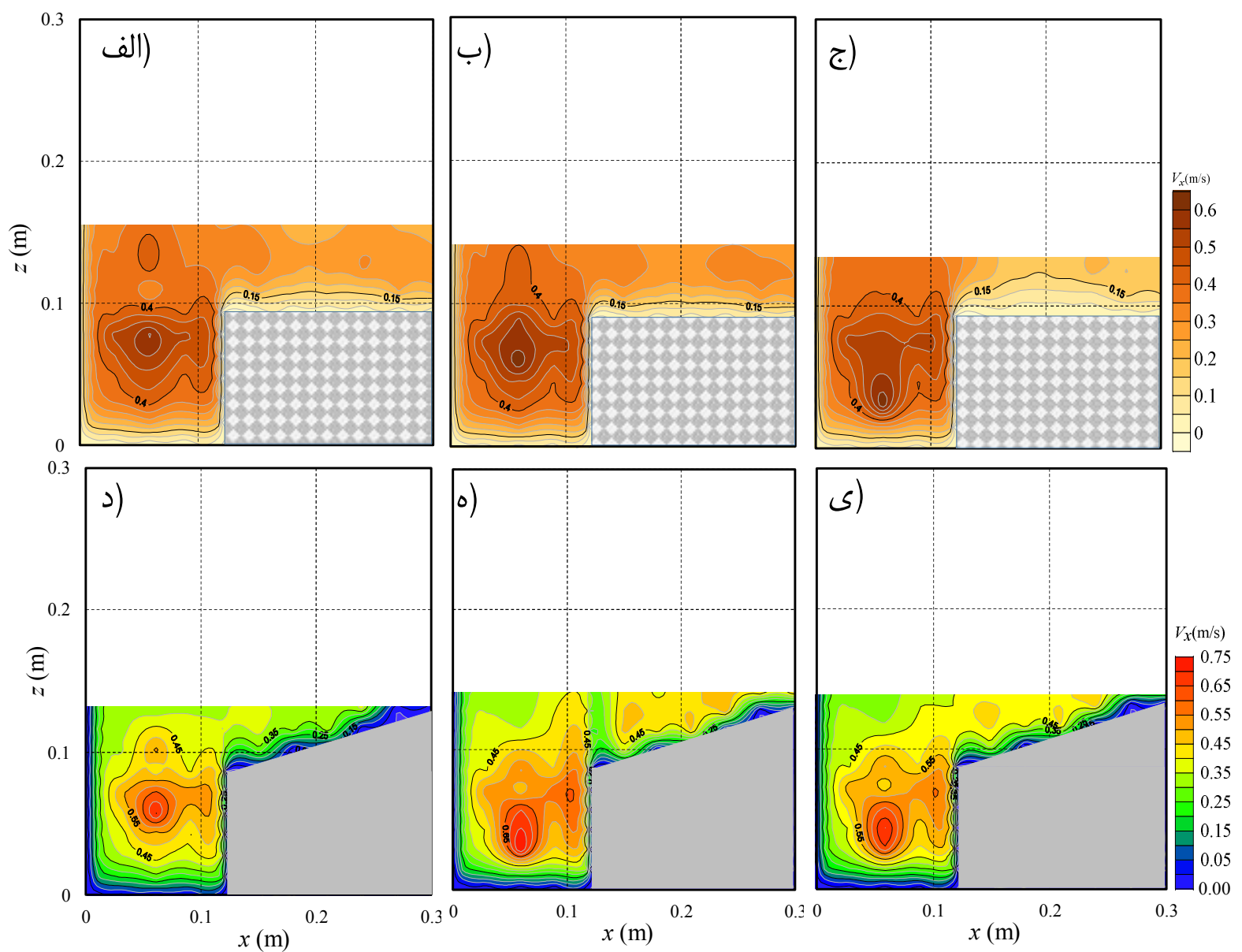

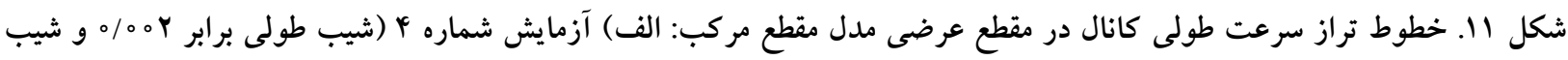

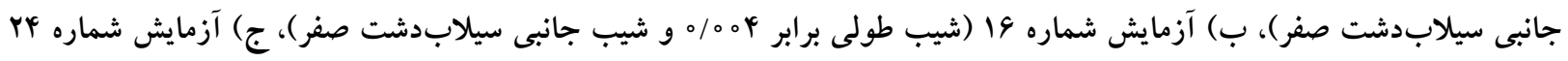

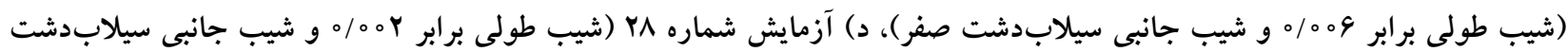

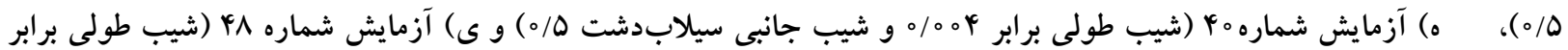

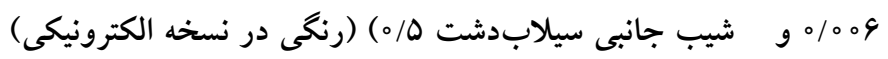

رخ مى دهد درحالى كه در روى سـيلابدشـت منطقـهاى بـا

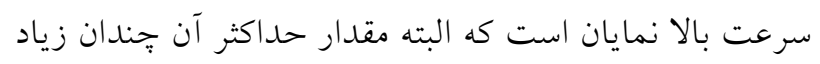

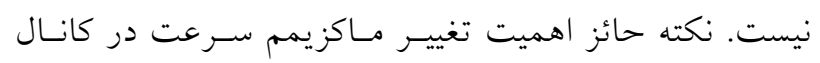
اصلى بهازاى تغيير شيب طولى و جانبى است. بههمين دليـل

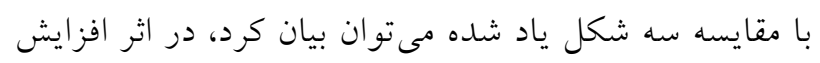
شيب طولى ماكزيمم سرعت بهسمت كف كانال اصلى تغييـر

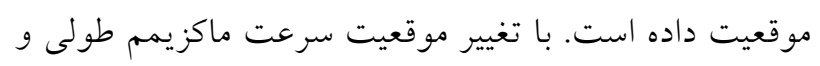

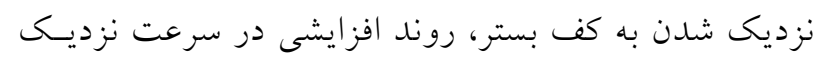

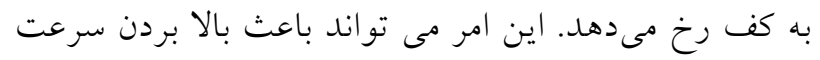

اندازهگيرى شد و بهازاى شيب هـاى طـولى و جـانبى مختلـف سيلابدشت و كانال اصلى در شكل (11) نشان داده شدند. سئل

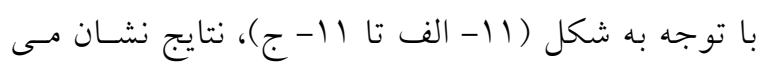

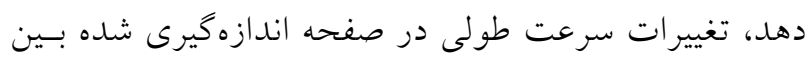

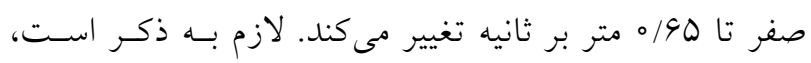

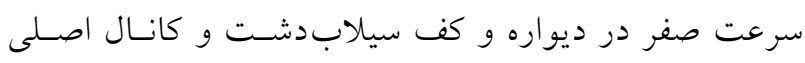
رخ مى دهد. همجينين در ادامسه مشـخص شــ كـه دو ناحيـه

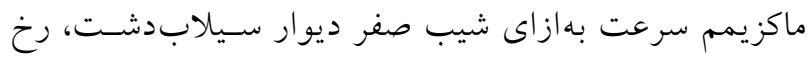

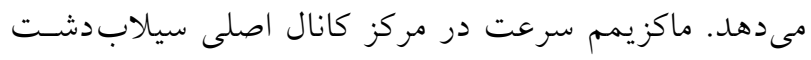


مىرسد يكى از عوامل تأثير كذار در افـزايش آبشستـى بـا افزايش شيب طولى و عرضى اين تغييـر وضسعيت سـرعت

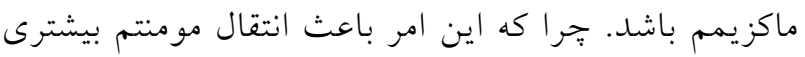

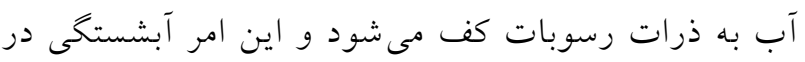
طول كانال را افزايش مىدهد. همجنين افزايش شيب، مقدار

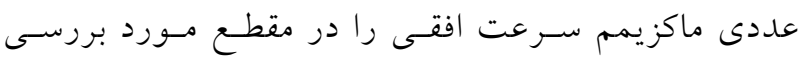

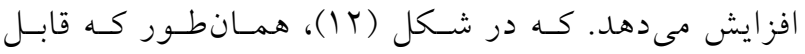

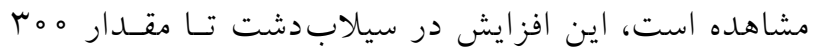

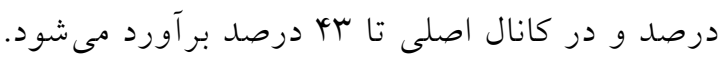
رابطه ارائه شده براى برآورد رسـوبات: بـا درنظـر خـرفتن

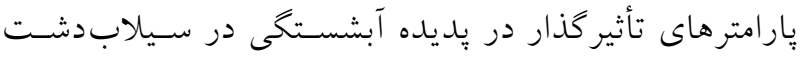

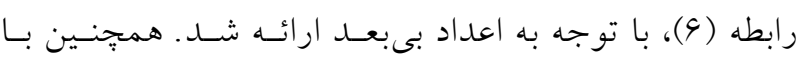

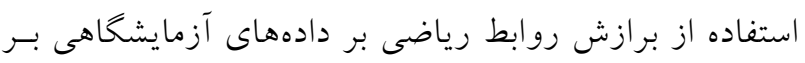

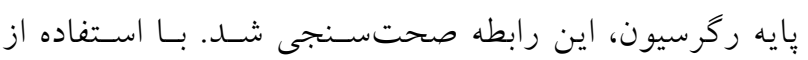

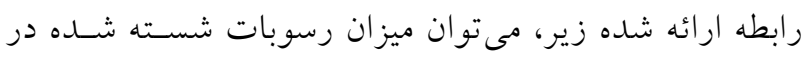

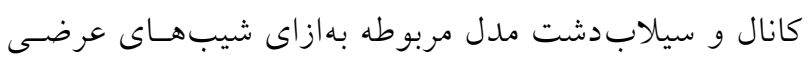

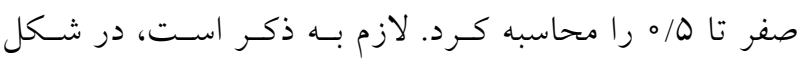

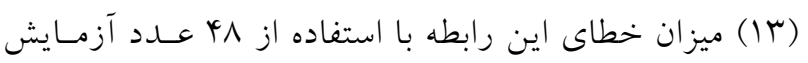

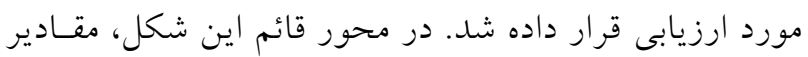
محاسبه شده از اعداد هيــروليكى استفاده شـــ و درنهايست

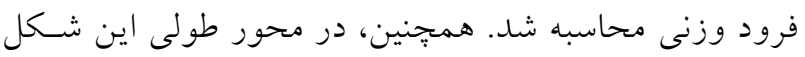
مقادير محاسبه شده از وزن رسوبات ارائه شد. در حالت ايده

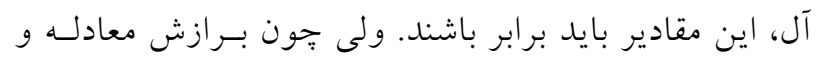

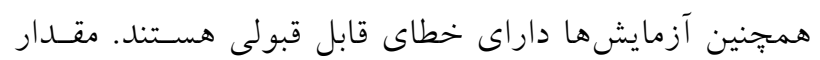

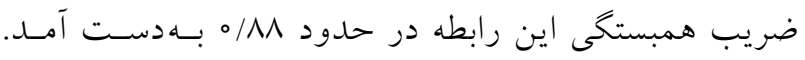

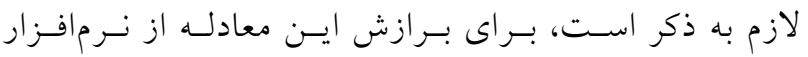
Mathematical

$$
\begin{aligned}
& \left(\frac{\mathrm{W}_{\text {out }} \mathrm{V}_{\text {avg }}}{\gamma_{\mathrm{s}} \sqrt{\mathrm{gho}} \mathrm{gh}^{3.5}}\right)=\mathrm{f}\left(\mathrm{Fr}, \frac{\mathrm{h}_{\mathrm{s}}}{\mathrm{h}_{\mathrm{o}}}, \frac{\mathrm{d}_{50}}{\mathrm{~h}_{\mathrm{o}}}, \mathrm{S}_{\mathrm{o}}, \mathrm{S}_{\mathrm{s}}\right) \\
& \left.\left(\frac{\mathrm{W}_{\text {out }} \mathrm{V}_{\text {avg }}}{\gamma_{\mathrm{s}} \sqrt{\mathrm{gho}^{3.5}}}\right)=[\mathrm{Fr}]^{\mathrm{c}_{1}}\left[\frac{\mathrm{h}_{\mathrm{s}}}{\mathrm{h}_{\mathrm{o}}}\right]^{\mathrm{c}_{2}}\left[\frac{\mathrm{d}_{50}}{\mathrm{~h}_{\mathrm{o}}}\right]^{\mathrm{c}_{3}}\left[\mathrm{~S}_{\mathrm{o}}\right]^{\mathrm{c}_{4}}\left[\mathrm{~S}_{\mathrm{s}}\right]^{\mathrm{c}_{5}}\right)
\end{aligned}
$$

برشى جريان شود. بهازاى افزايش اين مقدار و تجاوز كـردن

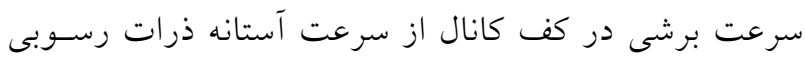

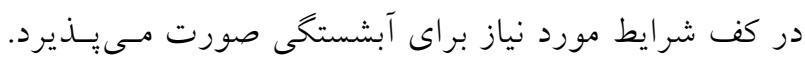

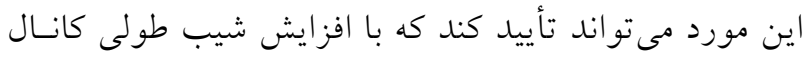

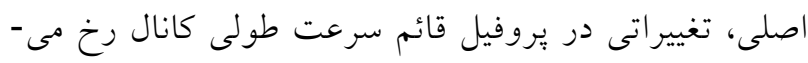

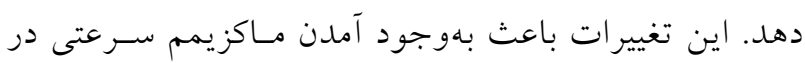

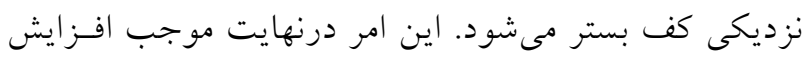

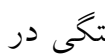

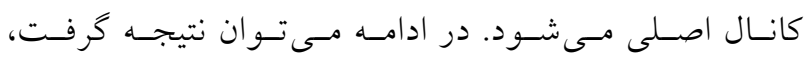

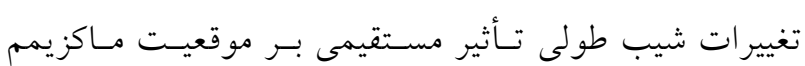

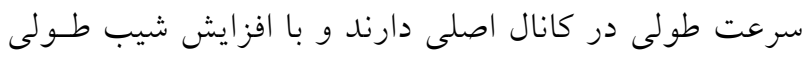
اين مقدار بهسمت كف حركت كرده و مقدارش افزايش ييدا

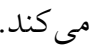

همجنين با توجه بـه شـكل (11-د تـا ا1-ى)، مقايسـهــا نشان مىدهد، تغييرات سرعت طولى در صفحه اندازهيرى شده

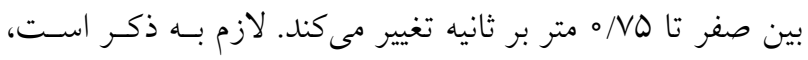

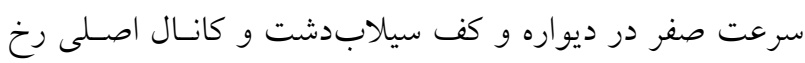

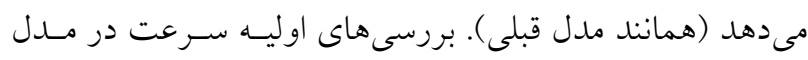

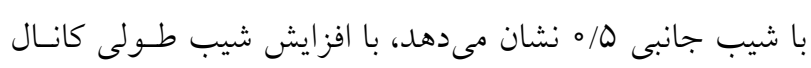
ماكزيمم سرعت طولى در كانال اصلى بهسمت كف كانال تغييـر

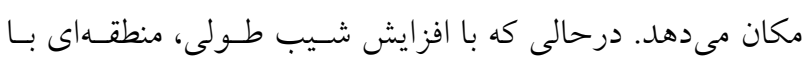

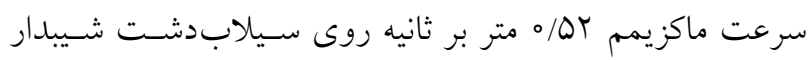

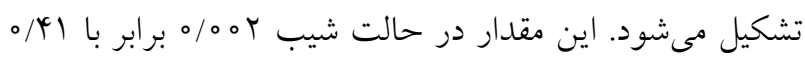

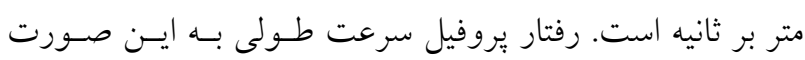

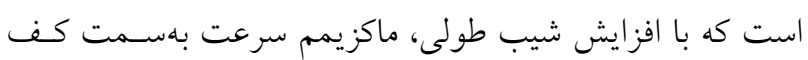

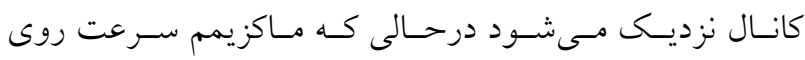
سيلابدشت ايجاد مىشود در شكل (I (I) مىتوان اين مقايسهها را مورد بررسى و ارزيابى قرار داد.

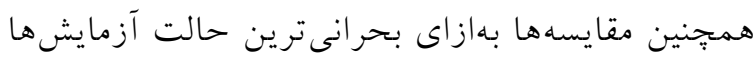

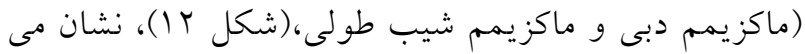

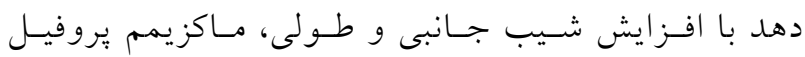
سرعت بهسمت كف كانال تغيير وضعيت مىدهـــ. بـهنظـر 


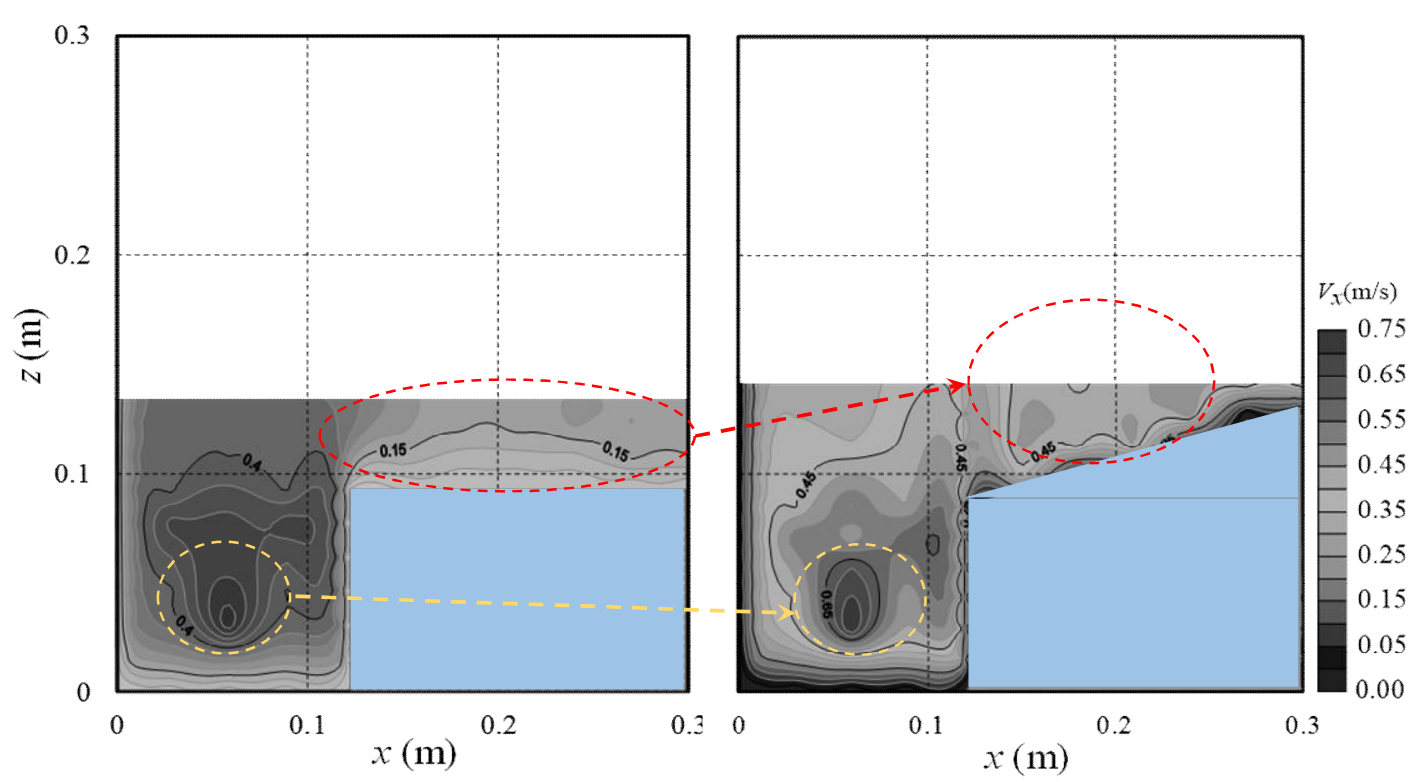

شكل rا. مقايسه بروفيل سرعت طولى كانال در مقطع عرضى مدل مقطع مركب (رنخى در نسخه الكترونيكى)

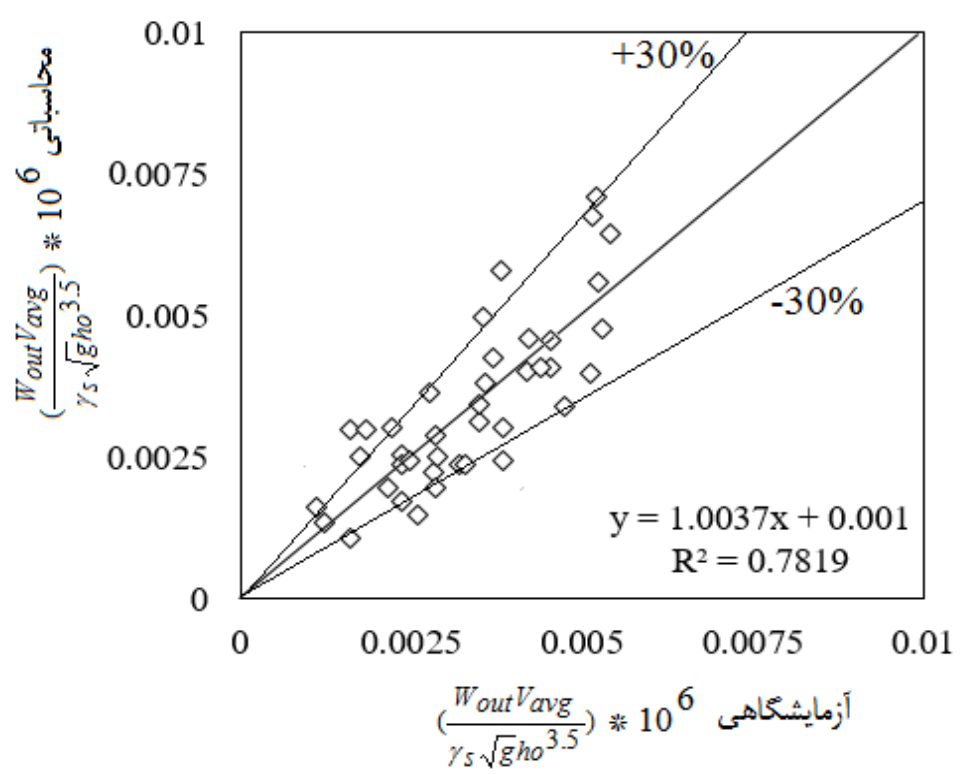

شكل rا. ميزان ضريب همبستخى فرمول ارائه شده براى برآورد ميزان رسوبات شسته شده در كانال اصلى

$$
\begin{aligned}
& \left(\frac{\mathrm{W}_{\text {out }} \mathrm{V}_{\mathrm{avg}}}{\gamma_{\mathrm{s}} \sqrt{\mathrm{gho}} \mathrm{go}^{3.5}}\right)= \\
& \left.\quad[\mathrm{Fr}]^{\mathrm{c}_{1}}\left[\frac{\mathrm{h}_{\mathrm{s}}}{\mathrm{h}_{\mathrm{o}}}\right]^{\mathrm{c}_{2}}\left[\frac{\mathrm{d}_{50}}{\mathrm{~h}_{\mathrm{o}}}\right]^{\mathrm{c}_{3}}\left[\mathrm{~S}_{\mathrm{o}}\right]^{\mathrm{c}_{4}}\left[\frac{\mathrm{b} \cos \theta}{\mathrm{b}}\right]^{\mathrm{c}_{5}}\right)
\end{aligned}
$$

$$
\text { ضرايب رابطه بهصورت زير ارائه مىشود: }
$$

ازآنجايى كه شيب جانبى سيلابدشـت در بعضى آزمـايشهـا

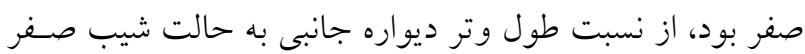
استفاده شد. (با توجه به شكل ץ ب- ب). با اين رويكرد مى تـوان،

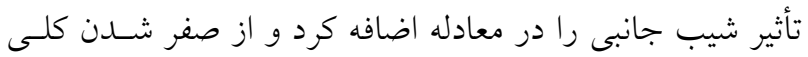
معادله جلو گيرى بهعمل آيد. درنهايت معادله بهصورت زير ارئه بهمل ائد شد: 


$$
\begin{aligned}
& \text { در كانال مركب ميـزان شسـته شــن رسـوبات و حجـم انتقـال } \\
& \text { رسوب افزايش بيدا مى كند. }
\end{aligned}
$$

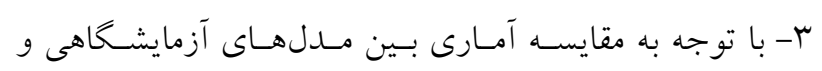

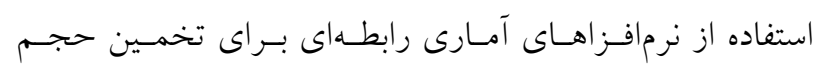

$$
\begin{aligned}
& \text { رسوبات شسته شده در طول كانال داده شد. }
\end{aligned}
$$

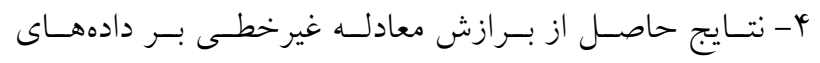

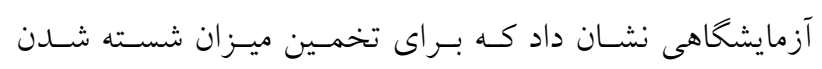

$$
\begin{aligned}
& \text { رسوبات، مىتوان از عدد فرود وزنى ارائه شـده درايسن تحقيـق } \\
& \text { استفاده كرد. } \\
& \text { ه- دادههاى سرعتسنجى ADV مى تواند بهعنوان ابزارى بـراى } \\
& \text { بررسى تأثير تغيير پيارامترهاى فيزيكى مانند شيب جانبى كانال و }
\end{aligned}
$$

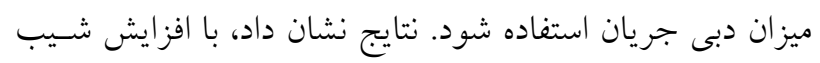

$$
\begin{aligned}
& \text { جانبى محل ماكزيمم سرعت افقى بـهــمت كـف كانسال تغييـر }
\end{aligned}
$$

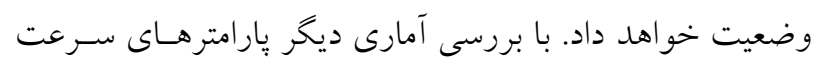

$$
\begin{aligned}
& \text { مىتوان تأثير ديخر اجزاى سرعت را بررسى كرد. } \\
& \text { 9- نتايج نشان داد، بـهازاى بحرانسىتـر شـــن جريــان در كانـال }
\end{aligned}
$$

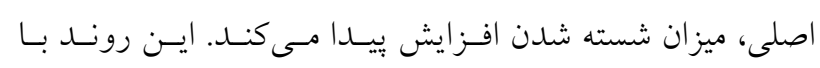

$$
\begin{aligned}
& \text { افزايش شيب جانبى، شدت بيشترى بيدا خو اهد كرد. } \\
& \begin{array}{l}
\left(\frac{\mathrm{W}_{\text {out }} \mathrm{V}_{\text {avg }}}{\gamma_{\mathrm{s}} \sqrt{\mathrm{gho}} \mathrm{gh}^{3.5}}\right)= \\
\quad[\mathrm{Fr}]^{1}\left[\frac{\mathrm{h}_{\mathrm{s}}}{\mathrm{h}_{\mathrm{o}}}\right]^{3}\left[\frac{\mathrm{d}_{50}}{\mathrm{~h}_{\mathrm{o}}}\right]^{0.001}\left[\mathrm{~S}_{\mathrm{o}}-0.49\left[\frac{\mathrm{b} \cos \theta}{\mathrm{b}}\right]^{0.05}\right)
\end{array} \\
& \text { در شكل (با) ميزان همبسـتخى دادههـاى آزمايشـخاهى بـا داده }
\end{aligned}
$$

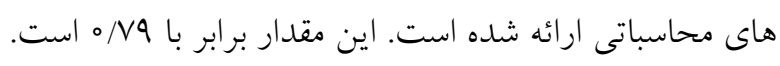

$$
\begin{aligned}
& \text { نتيجه گيرى } \\
& \text { در اين بخش به نتايج حاصل از اين تحقيق بـهـورت مـوردى } \\
& \text { اشاره شده است. } \\
& \text { ا- نتايج نشان داد، با افزايش شيب طولى، ميزان رسوبات شسته } \\
& \text { شده در كانال بهصورت افزايشى تغيير مى كند. همجنين مقايسـه }
\end{aligned}
$$

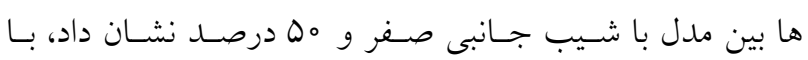

$$
\begin{aligned}
& \text { افزايش شيب جانبى روند افـزايش شسـته شــدن رسـوبات نيـز }
\end{aligned}
$$

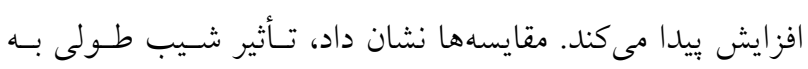

$$
\begin{aligned}
& \text { مراتب بيشتر از شيب عرضى است. }
\end{aligned}
$$

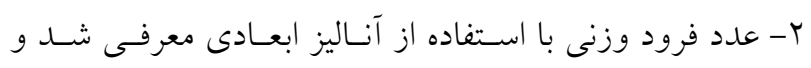

$$
\begin{aligned}
& \text { مقايسهها نشان داد با افزايش عدد فرود، عسدد فـرود وزنسى نيـز } \\
& \text { افزايش بيدا مى كند. اين بدان معناست با بحر انى تر شدن جريـان }
\end{aligned}
$$

\section{منابع مورد استفاده}

1. Ackers, P. 1992. Hydraulic design of two-stage channels. Journal of Water Marine Engineering 96: 247-257.

2. Ackers, P. 1993. Flow formulae for straight two-stage channels. Journal of Hydraulic. Research 31(4): $509-531$.

3. Bayley, P. B. 1995. Understanding large river: floodplain ecosystems. Bio-Science 45(3):153-158.

4. Chen, Y. H., J. Mossa and K. K. Singh. 2020. Floodplain response to varied flows in a large coastal plain river. Geomorphology 354: 107035.

5. Hamidifar. H. and M. Omid. 2013. Floodplain vegetation contribution to velocity distribution in compound channels. Journal of Civil Engineering Urbanism 3(6): 357-361.

6. Hin. L. S., N. Bessaih, L. P. Ling, A. A. Ghani, N. A. Zakaria and M. Seng. 2008. A study of hydraulic characteristics for flow in equatorial rivers. International Journal of River Basin Management 6(3): 213-223.

7. Gourevitch, J. D., N. K. Singh, J. Minot, K. B. Raub, D. M. Rizzo, B. C. Wemple and T. H. Ricketts. 2020. Spatial targeting of floodplain restoration to equitably mitigate flood risk. Global Environmental Change 61: 102050.

8. Karamisheva, R., J. F. Lyness, W. R. C. Myers and J. B. Cassells. 2005. Improving sediment discharge prediction for overbank flows. International Civil Enginners-Water Management 158(1): 17-24.

9. Karamisheva. R. D., J. F. Lyness, W. R. C. Myers, J. B. C. Cassells and J. O’Sullivan. 2006. Overbank flow depth prediction in alluvial compound channels. Proceedings of the Institution of Civil Engineers-Water Management 159(3):195-205.

10. Lambert M. F. and W. R. C. Myers. 1998. Estimating the discharge capacity in straight compound channels. Proceedings of the Institution of Civil Engineers. Water, Maritime \& Energy 130(2): 84-94. 
11. Martin, L. A. and R. C. Myers. 1991. Measurement of overbank flow in a compound river channel. Journal of Institution Water Environ Management 3(4): 645-657.

12. Mulahasn, S., T. Stoesser and R. McSherry. 2017. Effect of floodplain obstructions on the discharge conveyance capacity of compound channels. Journal of Irrigation and Drainage Enginnering 143(11): 1-11.

13. Nehal, L., Z. M. Yan, J. H. Xia and A. Khaldi. 2012. Flow through non-submerged vegetation. 16th International Water Technology Conference 16, IWTA, Alexandria, Egypt.

14. Tinoco. R. O. and E. A. Cowen. 2013. The direct and indirect measurement of boundary stress and drag on individual and complex arrays of elements. Experiments in Fluids 54(1509): 1-16.

15. Wormleaton. P. R., J. Allen and P. Hadjipanos. 1982. Discharge assessment in compound channel flow. Journal of Hydraulic Division 108(10): 975-993.

16. Zahiri, A., A. A. Dehghani and A. Hezarjeribi. 2012. Determination of stagedischarge curve for laboratory and river compound channels applying genetic algorithm. Journal of Water and Soil Conservation 19(2): 179-192. (In Farsi). 


\title{
Effect of Longitudinal and Side Slope of Flood Plain on Sediment Erosion in Compound Channel
}

\author{
A. Arab and K. Esmaili ${ }^{1 *}$ \\ (Received: June 18-2020 ; Accepted: September 19-2020)
}

\begin{abstract}
The study of floods has always been important for researchers due to the great loss of life and property. Investigation of flood bed can provide appropriate solutions to reduce this phenomenon to managers and researchers. In this research, the compound channel (with flood plain on one side of the main channel) Been paid, Therefore, two experimental models of compound channel in laboratory flume were examined by considering dimensional analysis. With the goal Investigation of lateral slope of flood wall in laboratory model In the first model, transverse slope 0 And in the second model, a value equal to $50 \%$ Was considered. Also in order to investigate the effect of longitudinal slope of river bed sediments Longitudinal slope in three steps 0.00 2, 0.004 and 0.006 Was changed. Examining the ADV speedometer data, the results showed that with increasing the longitudinal and transverse slope (slope of the flood wall) of the channel, the maximum longitudinal velocity changes to the floor of the channel. In order to investigate the effect of average sediment diameter on the scouring process during experiments $\mathrm{Mm}$ was used. The results showed that increasing the longitudinal and transverse slope had a great effect on increasing the volume of washed sediments 3 and 0.9 of sandy sediments with a diameter Along the canal and with the increase of these longitudinal and transverse slopes in the channel, more sediment transport volume occurs. In the following, using Investigation of dimensionless numbers obtained from dimensional analysis, dimensionless weight landing number was introduced to evaluate this value value of other hydraulic parameters and Was introduced. A relationship based on nonlinear regression with correlation coefficient Acceptable was introduced at around 0.88.
\end{abstract}

Keywords: compound channel, flood plain, longitudinal slope, sediment, side slope, Non-liner regression, Analytical solution.

1. Department of Water Engineering, Ferdowsi University of Mashhad, Iran.

Corresponding author, Email: esmaili@um.ac.ir 